\title{
THE (UN)PROTECTING AND (DIS) EMPOWERING POTENTIAL OF THE LAW AND HUMAN RIGHTS DISCOURSE WITHIN SOCIAL JUSTICE AND LAND CLAIMS*
}

\author{
EL POTENCIAL (DES)PROTECTOR Y \\ (DES)EMPODERADOR DEL DERECHO Y EL \\ DISCURSO DE LOS DERECHOS HUMANOS EN \\ RECLAMOS DE JUSTICIA SOCIAL Y TIERRAS
}

Astrid Liliana SÁnchez-Mejía**

Reception date: October $15^{\text {th }}, 2015$ Acceptance date: November $6^{\text {th }}, 2015$ Available online: November $30^{\text {th }}, 2015$

To CITE THIS ARTICle / PARA CITAR ESTE ARTíCUlO Sánchez-Mejía, Astrid Liliana, The (Un)Protecting and (Dis)Empowering Potential of the Law and Human Rights Discourse within Social Justice and Land Claims, 27 International Law, Revista Colombiana de Derecho Internacional, 199-146 (2015). http://dx.doi.org/10.11144/Javeriana.il15-27.upde

doi:10.11144/Javeriana.i115-27.upde

* I conducted this research within the activities of the legal clinic of Law and Territory of Javeriana University, which is one of the institutions that provide legal assistance to the Las Pavas case.

** Assistant Professor, Facultad de Ciencias Jurídicas, Pontificia Universidad Javeriana. Doctor of Juridical Science (SJD), University of California, Los Angeles - UCLA; LL.M. in Legal Theory, New York University - NYU; Magister en Derecho, Universidad de los Andes; Abogada, Pontificia Universidad Javeriana. I would like to thank Prof. Sally Merry, Prof. Richard A. Wilson, and Prof. Juan Felipe García for their thoughtful comments on earlierdrafts of this text. Contact: astrid.sanchez@javeriana.edu.co 


\begin{abstract}
This article explores the potential effects of the use of human rights in framing claims for achieving social change. The discourse of human rights provides a conception of social justice based on dignity and equality. Thus, calling upon the human rights discourse can support social justice and land claims. However, in practice, the effects of a legal mobilization of the human rights discourse include not only benefits, but also dilemmas and risks for social and political struggles. I argue that utilization of the human rights discourse seems not to be an ideal strategy for achieving social change and the protection of land rights. However, in some contexts this discourse strongly contributes to the empowerment of underprivileged and excluded people, making unjust situations visible, and offering an alternative reality based on equality and dignity. At the very least, it can become a symbol of those ideals, inspiring social mobilization for change.
\end{abstract}

Keywords: Social justice; human rights; victims’ rights; legal mobilization 
Este artículo explora los efectos potenciales del uso de los derechos humanos en la formulación de reclamos de cambio social. El discurso de los derechos humanos ofrece una concepción de justicia social fundamentada en dignidade igualdad. Por lo tanto, invocar los derechos humanos puede apoyar reclamos de justicia social y de protección del derecho a la tierra. En la realidad, los efectos del uso de los derechos humanos implican no solo beneficios, sino también dilemas y riesgos para las movilizaciones sociales y politicas. Este artículo sostiene que el derecho y los derechos humanos no parecen una estrategia ideal para lograr el cambio social y la protección del derecho a la tierra. Sin embargo, en algunos contextos, este discurso contribuye a empoderar a las personas o grupos tradicionalmente excluidos, haciendo visibles situaciones injustas y ofreciendo una realidad alternativa fundamentada en igualdad o dignidad. Al menos este discurso puede convertirse en un símbolo que inspira la movilización social.

Palabras clave: Justicia social; derechos humanos; derechos de las víctimas; movilización jurídica

\section{SUMMARY}

Introduction.- I. Methodology.- II. Background - The Las Pavas case.A. Relevant Facts.- B. Context.- 1. Violence and Forced Displacement.- 2. Inadequate Local and Regional Government Intervention.- 3. Competing Development Models.- 4. Land Disputes and Problems of Property Titling.- $C$. The Parties. - 1. The Las Pavas Community-ASOCAB.- 2. The Labrador Consortium.- 3. Asymmetry between the Parties.- III. ThE Two FACES OF LAW AND HUMAN RIGHTS WITHIN SOCIAL JUSTICE AND LAND CLAIMS.- $A$. The protecting and empowering potential of law and human rights in the Las Pavas case.- B. The unprotecting and disempowering potential of law and human rights in the Las Pavas case.- ConClusion.- BiBliography. 
INTRODUCTION

The human rights discourse provides a conception of social justice based on dignity and equality. Thus, the language of human rights can support the claims to social and political reform made by activists, victims, social organizations, and social movements with transformative agendas. However, the legal mobilization of this framework can have two faces in the protection of rights. On one hand, it may offer a political space for reform founded on a language legitimated by a global consensus, and thus it possesses a protecting and empowering potential. On the other hand, legal mobilization of the human rights discourse may generate risks or limits to emancipation, which means that it may involve an unprotecting and disempowering potential. In particular, the legal mobilization within the institution of criminal justice may have this effect of unprotecting victims. Contributing to the literature on rights, legal mobilization, and emancipation, ${ }^{1}$ this paper explores the two faces of the legal mobilization of the human rights discourse by specifically analyzing the Las Pavas case. Above all, the issue at stake is how the legal mobilization of this discourse within social justice and land claims operates in practice.

\section{Methodology}

I will analyze the two faces of human rights law within land claims in Colombia following the dispute-processing model, which is based on a dynamic perspective that considers the dispute as one event among several linking persons and groups. As

1 Mauricio García-Villegas \& Rodrigo Uprimny-Yepes, Corte Constitucional y emancipación social, en Emancipación social y violencia en Colombia, 463-511 (Boaventura de Sousa-Santos \& Mauricio García-Villegas, Norma, Bogotá, 2004). Mauricio García-Villegas, El derecho como esperanza: constitucionalismo y cambio social en América Latina, con algunas ilustraciones a partir de Colombia, in ¿Justicia para todos? Sistema judicial, derechos sociales y democracia en Colombia, 201-233 (Rodrigo Uprimny-Yepes, César Rodríguez-Garavito \& Mauricio García-Villegas, eds., Norma, Bogotá, 2006). Isabel Cristina Jaramillo-Sierra \& Tatiana Alfonso-Sierra, Mujeres, cortes y medios: la reforma judicial del aborto (Universidad de los Andes, Siglo del Hombre Editores, Bogotá, 2008). 
a result, the focus of attention in this model is process, interaction, decision-making, and agency. ${ }^{2}$ The scope of this approach includes not only analysis of bureaucratic institutions, such as courts, but also of the litigants' perspective. ${ }^{3}$ Furthermore, this paper examines the emergence and transformation of disputes as a social process in which individuals are creators of opportunities for law and legal activity. The emergence and transformation of disputes may be explained using the theoretical framework of "naming, blaming, and claiming." This approach examines "the processes by which unperceived injurious experiences are-or are not-perceived (naming), do or do not become grievances (blaming), and ultimately disputes (claiming), as well as for subsequent transformations." 4

The methodology of the disputing approach is based primarily on the case method. It seeks to examine how the law works and to understand the role of an institution and the meaning of the conflict for the parties, taking into account their origins, context, and relationships. ${ }^{5}$ Consequently, I will analyze my research question through an observed case: the Las Pavas case. ${ }^{6}$ It is important to note that this case is representative of forced displacement and land restitution in the country, since it is considered to be an emblematic human rights violation example

2 John L. Comaroff \& Simon Roberts, Rules and Processes: The Cultural Logic of Dispute in an African Context, 12 (University of Chicago Press, Chicago, 1981). Laura Nader \& Harry F. Todd, eds., The Disputing Process: Law in Ten Societies, 1, 4, 5, 15 (Columbia University Press, New York, 1978). David M. Trubek, Studying Courts in Context, 15 Law \& Society Review, 3/4, 485-502 (1980).

3 John L. Comaroff \& Simon Roberts, Rules and Processes: The Cultural Logic of Dispute in an African Context, 12, 14 (University of Chicago Press, Chicago, 1981).

4 William L. F. Felstiner, Richard L. Abel \& Austin Sarat, The Emergence and Transformation of Disputes: Naming, Blaming, Claiming..., 15 Law \& Society Review, 3/4, 631-654 (1980). Available at: http://www-personal.umich.edu/ 1root/ConflictMgtConceptMap/ Felstiner-Abel-Sarat-Emergence-of-Disputes-1981.pdf

5 William L. F. Felstiner, Richard L. Abel \& Austin Sarat, The Emergence and Transformation of Disputes: Naming, Blaming, Claiming..., 15 Law \& Society Review, 3/4, 631-654, 639 (1980). Available at: http://www-personal.umich.edu/ 1root/ConflictMgtConceptMap/ Felstiner-Abel-Sarat-Emergence-of-Disputes-1981.pdf. Laura Nader \& Harry F. Todd, eds., The Disputing Process: Law in Ten Societies (Columbia University Press, New York, 1978).

6 This paper will emphasize on the decision-making of the community of Las Pavas, since the research issue is the role of law within social justice and land claims, and moreover the community and its supporters have the transformative agenda. 
both by the Colombian State ${ }^{7}$ and by social organizations. ${ }^{8}$ This case study of Las Pavas is based on information collected since 2009 through several sources, such as dialogues with key actors and experts, analysis of relevant documents, and mass media information.

Some scholars have criticized the disputing process paradigm because its micro-level approach is considered ineffective in the study of political and power relationships. ${ }^{9}$ In order to deal with this critique, this article will use the idea of the relative autonomy of the law as an analytical framework. This analysis will show the role of the law within contexts of social inequality, domination, and social justice claims.

\section{Background - The Las Pavas case}

The dispute analysis involves the examination of the sociocultural context, social structural variables, the relationship between the parties, and individual characteristics such as class, ethnicity, gender, and age..$^{10}$ Therefore, in this section of the paper, I will briefly describe the context of the Las Pavas case in

7 In October 2010 the Ministry of Agriculture (Ministerio de Agricultura) launched a plan for land restitution in Colombia (Plan de Choque de Restitución y Formalización de Tierras), which includes the Las Pavas case as emblematic. MinAgricultura activó plan de choque para restituir y formalizar tierras a 130 mil familias. Available at: http://wsp. presidencia.gov.co/Prensa/2010/Octubre/Paginas/20101015_06.aspx

8 Corporación Sembrar and Federación Agrominera del Sur de Bolívar, FEDEAGROMISBOL, considered that the situation in Las Pavas reflects the situation of dispossession of peasants in Colombia. Corporación Sembrar \& Federación Agrominera del Sur de Bolívar, FEDEAGROMISBOL, Caso Hacienda Las Pavas. Los intereses económicos $y$ políticos del despojo del territorio (n.d.). Available at: http://retornoalaspavas.files. wordpress.com/2011/02/intereses-politicos-y-economicos-del-despojo-las-pavas.pdf

9 Richard L. Abel, The Rise of Capitalism and the Transformation of Disputing: from Confrontation over Honor to Competition for Property, 27 University of California at Los Angeles, UCLA Law Review, 223-255 (1979).

10 John L. Comaroff \& Simon Roberts, Rules and Processes: The Cultural Logic of Dispute in an African Context, 14 (University of Chicago Press, Chicago, 1981). William L. F. Felstiner, Richard L. Abel \& Austin Sarat, The Emergence and Transformation of Disputes: Naming, Blaming, Claiming..., 15 Law \& Society Review, 3/4, 631-654, 640 (1980). Available at: http://www-personal.umich.edu/ /root/ConflictMgtConceptMap/FelstinerAbel-Sarat-Emergence-of-Disputes-1981.pdf. Laura Nader \& Harry F. Todd, eds., The Disputing Process: Law in Ten Societies, 4, 5, 8, 13, 16, 18 (Columbia University Press, New York, 1978). 
order to explain the major factors influencing the community's decision-making regarding this dispute.

\section{A. Relevant facts ${ }^{11}$}

In 1983, Jesús Emilio Escobar bought the lots of Si Dios quiere, No te canses, Peñaloza, and Las Pavas and other farms, adding up to a total of 1,717 hectares, which later he called Las Pavas. In the 1990s, Escobar left the farm, allowing the peasants from a neighboring village to begin partial occupation and use of the lots in 1997.

In 2003, members of the paramilitary group Central Bolívar Bloc (Bloque Central Bolívar, BCB of the United Colombian Self-Defense, Autodefensas Unidas de Colombia, AUC) forced the community to abandon their agricultural operations in Las Pavas, triggering a massive forced displacement of 123 families. During the following years, the peasants slowly reoccupied the land they left due to the lack of alternative economic activities and the demobilization of some paramilitary groups.

In 2006, the community created the Buenos Aires Peasants Association (Asociación de Campesinos de Buenos Aires, ASOCAB), and requested the Colombian Institute for Rural Development (Instituto Colombiano de Desarrollo Rural, INCODER) to issue a judgment regarding Las Pavas through the process of extinction of property (extinción de dominio). They argued the land should be declared as abandoned since, as required under Colombian law, there was a lack of exploitation by the owner (Jesús Emilio Escobar). Following this procedure, in June 2006, an INCODER representative visited the farm and witnessed the occupation and agricultural activities by the peasants.

In September 2006, an armed group threatened the peasants of ASOCAB and destroyed their crops, generating a second

11 Constitutional Court, Judgment T-267-11, April 8, 2011, reporting justice Mauricio González-Cuervo. Available at: http://www.corteconstitucional.gov.co/relatoria/2011/t-267-11. htm, http://english.corteconstitucional.gov.co/sentences/T-267-2011.pdf 
forced displacement. In March 2007, Escobar transferred the title of the property and delivered the land to the Labrador Consortium, a group of powerful corporations that operate palm plantations.

B. Context

Las Pavas is a farm located in the town of El Peñón in the Magdalena Medio Region, which is a very complex region due to the following factors: ${ }^{12}$

\section{Violence and Forced Displacement}

This is one of the most turbulent regions in the country, due to a high presence of violent non-state actors including leftist guerrillas (Ejército de Liberación Nacional, ELN and Fuerzas Armadas Revolucionarias de Colombia, FARC) and paramilitary groups (Autodefensas Unidas de Colombia). In the context of the Colombian armed conflict, forced displacement is a recurrent crime. This has generated the dispossession of 6,638,195 hectares by force or violence, which is about $15.4 \%$ of the total agricultural land in the country. ${ }^{13}$ According to the Victims Register, 6,163,500 people were victims of forced displacement in Colombia, between 1984 and 2015. ${ }^{14}$ Particularly, in El Peñón,

12 For an overview of the conflict and its context, Independent Commission Land Conflict - Las Pavas, Report Independent Evaluation of the Land Conflict in Las Pavas, Bolivar, Colombia (Ricardo Vargas, June Marie Mow, Mario Pérez \& Ángela Rivas, Body Shop, Christian Aid, June 2010). Available at: http://www.abcolombia.org.uk/downloads/361_ LasPavasReview_Spanish.pdf, http://www.christianaid.org.uk/images/laspavasreport. pdf

13 Comisión de Seguimiento a la Política Pública sobre el Desplazamiento Forzado, Consultoría para los Derechos Humanos y el Desplazamiento, CODHES, Proceso Nacional de Verificación, El reto ante la tragedia humanitaria del desplazamiento forzado: reconocer y resarcir debidamente los daños y perjuicios, 22 (2009). Available at: http://www.codhes.org/ codhes/images/Encuestas/Vol $\% 2010 \% 20$ reconocer $\% 20 y \% 20$ resarcir $\% 20$ debidamente $\% 201$ os $\% 20$ daos $\% 20$ sept $\% 202011$.pdf

14 National Victims Unit, Victims Register: http://rni.unidadvictimas.gov.co/?q=node/107, http://www.unidadvictimas.gov.co/. Notably, there have been many efforts to measure forced displacement by state institutions, NGOs, and international organizations, which collect and report different data. CODHES states that 5,921,229 people were victims of forced displacement, between 1985 and 2013. Consultoría para los Derechos Humanos y el Desplazamiento, CODHES, El desplazamiento forzado y la imperiosa necesidad 
Human Rights Discourse within Social Justice and Land Claims

840 persons were victims of forced displacement in $2002 .{ }^{15}$ The majority of the victims of forced displacement belong to the most excluded and underprivileged sectors in the country.

\section{Inadequate Local and Regional Government Intervention}

The local and regional state institutions in El Peñón are very weak, and they depend upon national programs of financial assistance. "The financial crisis in the municipality and the high percentage of its income spent on bureaucratic expenses is reflected in its failure to adequately provide public services."16 Therefore, the Unsatisfied Basic Needs index is over $70 \%$ in $\mathrm{El}$ Peñón. ${ }^{17}$ Notably, inhabitants of Buenos Aires have to face very limited educational and health systems and a lack of communications and transport infrastructure. ${ }^{18}$ Furthermore, in some cases, local and regional state representatives have become co-opted by non-state actors of the armed conflict and elites (powerful private individuals and corporations).

de la paz, Informe Desplazamiento 2013 (Consultoría para los Derechos Humanos y el Desplazamiento, CODHES, Bogotá, 2014). Available at: http://www.acnur.org/t3/ uploads/media/2881_COI_Colombia_Informe_CODHES_2013.pdf?view=1. According to the UNCHR, there were 6,520,270 victims of forced displacement in Colombia as of June 2015. United Nations High Commissioner for Refugees, UNCHR, 2015 UNHCR country operations profile - Colombia. Available at: http://www.unhcr.org/cgi-bin/texis/ $\mathrm{vtx} /$ page?page $=49 \mathrm{e} 492 \mathrm{ad} 6 \&$ submit $=\mathrm{GO}$

15 Independent Commission Land Conflict - Las Pavas, Report Independent Evaluation of the Land Conflict in Las Pavas, Bolivar, Colombia, 26 (Ricardo Vargas, June Marie Mow, Mario Pérez \& Ángela Rivas, Body Shop, Christian Aid, June 2010). Available at: http:// www.abcolombia.org.uk/downloads/361_LasPavasReview_Spanish.pdf, http://www. christianaid.org.uk/images/laspavasreport.pdf

16 Independent Commission Land Conflict - Las Pavas, Report Independent Evaluation of the Land Conflict in Las Pavas, Bolivar, Colombia, 26 (Ricardo Vargas, June Marie Mow, Mario Pérez \& Ángela Rivas, Body Shop, Christian Aid, June 2010). Available at: http:// www.abcolombia.org.uk/downloads/361_LasPavasReview_Spanish.pdf, http://www. christianaid.org.uk/images/laspavasreport.pdf

17 Independent Commission Land Conflict - Las Pavas, Report Independent Evaluation of the Land Conflict in Las Pavas, Bolivar, Colombia, 27 (Ricardo Vargas, June Marie Mow, Mario Pérez \& Ángela Rivas, Body Shop, Christian Aid, June 2010). Available at: http:// www.abcolombia.org.uk/downloads/361_LasPavasReview_Spanish.pdf, http://www. christianaid.org.uk/images/laspavasreport.pdf

18 Independent Commission Land Conflict - Las Pavas, Report Independent Evaluation of the Land Conflict in Las Pavas, Bolivar, Colombia, 28 (Ricardo Vargas, June Marie Mow, Mario Pérez \& Ángela Rivas, Body Shop, Christian Aid, June 2010). Available at: http:// www.abcolombia.org.uk/downloads/361_LasPavasReview_Spanish.pdf, http://www. christianaid.org.uk/images/laspavasreport.pdf 


\section{Competing Development Models}

In the region, there is a broad conflict between two rural development models. On one hand, there is a traditional model that is based on the traditional agricultural practice of local farmers, which is mainly the sowing of basic crops aimed at ensuring the subsistence of their own family and community, and meeting local and regional demand. ${ }^{19}$ Some local farmers, peasants, and their supporters have defended this model through legal claims of their right to land and culture. They argue that the traditional model preserves the customs and traditions of local communities, an argument which borrows from claims to cultural preservation raised by indigenous movements. ${ }^{20}$

On the other hand, there is an agro-industrial model that encourages the investment of large corporations in monocultures, such as palm oil. Private corporations and the Colombian national government ${ }^{21}$ have promoted this model within national and global discourses of rural development and modernization. ${ }^{22}$ They argue that this model has potential positive effects on the national and regional economy, using a language that is similar to how civilization was discussed in colonial projects. This discourse suggests significant cultural, political, and economic transformations. ${ }^{23}$ Moreover, the agro-industrial model sets new

19 Independent Commission Land Conflict - Las Pavas, Report Independent Evaluation of the Land Conflict in Las Pavas, Bolivar, Colombia, 9 (Ricardo Vargas, June Marie Mow, Mario Pérez \& Ángela Rivas, Body Shop, Christian Aid, June 2010). Available at: http:// www.abcolombia.org.uk/downloads/361_LasPavasReview_Spanish.pdf, http://www. christianaid.org.uk/images/laspavasreport.pdf

20 Jane K. Cowan, Marie-Bénédicte Dembour \& Richard A. Wilson, eds., Culture and Rights: Anthropological Perspectives (Cambridge University Press, Cambridge, New York, 2001).

21 The Colombian government has projected that, in 2020, the production of palm oil will be 3.4 million ton and the area sowed with oil palms will be 996 million hectares. DNP, Departamento Nacional de Planeación (2010). Estadísticas del Sector Agropecuario. Ministerio de Comercio, Industria y Turismo de Colombia, MinCIT (2010). Apuesta exportadora agropecuaria. Cultivos de tardio rendimiento.

22 Independent Commission Land Conflict - Las Pavas, Report Independent Evaluation of the Land Conflict in Las Pavas, Bolivar, Colombia, 29, 30, 52, 53 (Ricardo Vargas, June Marie Mow, Mario Pérez \& Ángela Rivas, Body Shop, Christian Aid, June 2010). Available at: http://www.abcolombia.org.uk/downloads/361_LasPavasReview_Spanish.pdf, http:// www.christianaid.org.uk/images/laspavasreport.pdf

23 Sally Engle Merry, Colonizing Hawai' $i$ : The Cultural Power of Law, 258 (Princeton University Press, Princeton, New Jersey, 2000). 
cultural meanings of territory. Critics of this model have highlighted its negative effects. Primarily, the agro-industrial model increases vulnerability of local communities and facilitates the dispossession of peasants, turning them into landless people. The agro-industrial model and monocultures also reduce local production of food, affecting availability of basic foods and increasing food prices. Furthermore, monocultures and intensive agriculture entail environmental and social costs. ${ }^{24}$

\section{Land Disputes and Problems of Property Titling}

In the Colombian internal armed conflict, the issue of land has played a central role as one of its causes, objectives, and consequences. There are serious issues of unequal distribution of land ownership and forced dispossession in the country. ${ }^{25}$ The systematic practice of land dispossession through violence has been facilitated by diverse factors, including: i) the lack of an accurate and updated information system on property titles, ${ }^{26}$ and ii) the peasant occupation of land based on uncertain or precarious rights that are based on very informal local practices. These conditions have generated generalized problems regarding the clarity of property titles, which allows usurpers to easily "legalize" the dispossession. ${ }^{27}$

24 María Silvia Emanuelli, Jennie Jonsén \& Sofía Monsalve-Suárez, Red Sugar, Green Deserts: Latin American Report on Monocultures and Violations of the Human Rights to Adequate Food and Housing, to Water, to Land and to Territory (FIAN International/ FIAN Sweden, formerly FoodFirst Information and Action Network, Halmstad, Sweden, 2009). Available at: http://www.fian.org/en/news/article/red_sugar_green_deserts_ report_on_monocultures_and_human_rights/

25 María Paula Saffon, The Project of Land Restitution in Colombia: An Illustration of the Civilizing Force of Hypocrisy?, 12 Revista Estudios Socio-Jurídicos, 2, 109-194, 126 (2010). Available at: http://revistas.urosario.edu.co/index.php/sociojuridicos/article/ viewFile/1368/1258

26 María Paula Saffon, The Project of Land Restitution in Colombia: An Illustration of the Civilizing Force of Hypocrisy?, 12 Revista Estudios Socio-Jurídicos, 2, 109-194, 128 (2010). Available at: http://revistas.urosario.edu.co/index.php/sociojuridicos/article/ viewFile/1368/1258

27 "In Colombia, the methods used by armed actors for legalizing appropriated land have commonly included: the falsification of deeds over non-registered land, bribing or coercion of public officers to register them, purchase of land under coercion through figureheads or front men, and the application of legal schemes originally intended to protect landholders, such as prescription and false tradition." María Paula Saffon, The Project of Land 
The Las Pavas case evidences this complex situation of uncertain property titles and land disputes. In fact, Palmas de Tumaco S. A. - a company that had the first chance to purchase Las Pavas - refused to buy this land for two reasons. First, this company "did not fully trust the land titles of the Las Pavas farm." ${ }^{28}$ Second, company executives realized that members of the local community expected that INCODER would grant them the lots. ${ }^{29}$

\section{The Parties}

\section{The Las Pavas Community - ASOCAB}

In 1998, a group of peasants created the Farmers' Association of Buenos Aires (ASOCAB). Its purpose was "producing, marketing, and processing agricultural products, developing agroforestry and pasture programs, providing healthcare services to the community, increasing awareness and training for the purpose of assuming a leading role in the modern State, and highlighting the history of organizations, assuming leadership in locating productive employment to elevate economic living conditions." 30

The Las Pavas community is an example of the traditional development model. Peasants of Las Pavas have used the land for self-subsistence and small-scale agricultural production. In their

Restitution in Colombia: An Illustration of the Civilizing Force of Hypocrisy?, 12 Revista Estudios Socio-Jurídicos, 2, 109-194, 128 (2010). Available at: http://revistas.urosario.edu. co/index.php/sociojuridicos/article/viewFile/1368/1258

28 Independent Commission Land Conflict - Las Pavas, Report Independent Evaluation of the Land Conflict in Las Pavas, Bolivar, Colombia, 35 (Ricardo Vargas, June Marie Mow, Mario Pérez \& Ángela Rivas, Body Shop, Christian Aid, June 2010). Available at: http:// www.abcolombia.org.uk/downloads/361_LasPavasReview_Spanish.pdf, http://www. christianaid.org.uk/images/laspavasreport.pdf

29 Independent Commission Land Conflict - Las Pavas, Report Independent Evaluation of the Land Conflict in Las Pavas, Bolivar, Colombia, 35 (Ricardo Vargas, June Marie Mow, Mario Pérez \& Ángela Rivas, Body Shop, Christian Aid, June 2010). Available at: http:// www.abcolombia.org.uk/downloads/361_LasPavasReview_Spanish.pdf, http://www. christianaid.org.uk/images/laspavasreport.pdf

30 Act of constitution of ASOCAB (516 of the Chamber of Commerce of the city of Magangué, requested on October $3^{\text {rd }}, 1998$ and granted on December $15^{\text {th }}$ of the same year). 
Human Rights Discourse within Social Justice and Land Claims

agricultural activities, they have attempted to maintain their traditions based on a sacred meaning of territory. It is important to note that their social relationships are based on solidarity. ${ }^{31}$

\section{The Labrador Consortium}

Aportes San Isidro and Comercializadora Internacional CI- Tequendama (a company of the Daabon Group) created the Labrador Consortium to buy Las Pavas. This consortium's main "objective is the production of oil for bio-diesel. The plan involves 60,000 tons/year of oil palm fruits and the construction of an extractive plant at Regidor, specifically at the Camagüey farm of César Gil. This major business opportunity will be further enhanced through the establishment of a free trade zone in the area." ${ }^{32}$ It is evident that the consortium has huge economic power in comparison with the local and regional state institutions. A recent report stated that "the investments required by the El Labrador Consortium to set up 2000 hectares of palm (US\$16 million) are equivalent to around six years of El Peñón's municipal budget." ${ }^{{ }_{33}}$ In 2010, Daabon sold its share in the Labrador Consortium to Aportes San Isidro.

31 Independent Commission Land Conflict - Las Pavas, Report Independent Evaluation of the Land Conflict in Las Pavas, Bolivar, Colombia, 28 (Ricardo Vargas, June Marie Mow, Mario Pérez \& Ángela Rivas, Body Shop, Christian Aid, June 2010). Available at: http:// www.abcolombia.org.uk/downloads/361_LasPavasReview_Spanish.pdf, http://www. christianaid.org.uk/images/laspavasreport.pdf

32 Independent Commission Land Conflict - Las Pavas, Report Independent Evaluation of the Land Conflict in Las Pavas, Bolivar, Colombia, 19 (Ricardo Vargas, June Marie Mow, Mario Pérez \& Ángela Rivas, Body Shop, Christian Aid, June 2010). Available at: http:// www.abcolombia.org.uk/downloads/361_LasPavasReview_Spanish.pdf, http://www. christianaid.org.uk/images/laspavasreport.pdf

33 Independent Commission Land Conflict - Las Pavas, Report Independent Evaluation of the Land Conflict in Las Pavas, Bolivar, Colombia, 27 (Ricardo Vargas, June Marie Mow, Mario Pérez \& Ángela Rivas, Body Shop, Christian Aid, June 2010). Available at: http:// www.abcolombia.org.uk/downloads/361_LasPavasReview_Spanish.pdf, http://www. christianaid.org.uk/images/laspavasreport.pdf 
3. Asymmetry between the Parties

There is an unequal political, social, and economic power relationship between ASOCAB and the Labrador Consortium, and this inequality is reproduced in the advantages that the consortium has in access to justice and institutional mechanisms for dealing with the conflict. Mr. Misael Payares, one of the leaders of the Las Pavas community, highlights this disparity: "This case is the word of a peasant against the word of a businessman who has supported the election of the Mayor, Governor, Congressmen, etc." 34

This asymmetric situation is central to Marc Galanter's explanation of why the "haves" tend to come ahead. Galanter highlights that these parties have several advantages, such as i) their strategic social and economic position; ii) their ability to buy specialized and skillful legal services; iii) the existence of favorable rules; iv) the passivity, cost, and delay of legal proceedings; and v) barriers of institutional facilities. ${ }^{35}$ Above all, asymmetry has been fostered by the role played by local and regional state representatives within the Las Pavas conflict.

The asymmetric relationship has affected possibilities of achieving a negotiated solution to the conflict. In 2007 and 2008, there were some attempts to avoid the institutionalization of this conflict. While the Peace and Development Program of Magdalena Medio (Programa de Desarrollo y Paz del Magdalena Medio, PDPMM) tried to promote a negotiation process between the parties as an alternative to litigation within a Mesa de Diálogo, this approach was ultimately unsuccessful.

...the presumption that the Consortium was acting simultaneously outside of the Mesa de Diálogo, with the aim of obtaining its legal claims by using

34 Misael Payares: "Es la palabra de un campesino contra la de un empresario" (December 5, 2011). Available at: http://www.confidencialcolombia.com/noticia.html?noticia_ id $=4354 \&$ status $=\mathrm{T}$

35 Marc Galanter, Why the "Haves" Come out Ahead: Speculations on the Limits of Legal Change, 9 Law and Society Review, 1, Litigation and Dispute Processing: Part One, 95160 (1974). Available at: http://lawforlife.org.uk/wp-content/uploads/2013/05/whythehavescomeoutahead-33.pdf 
Human Rights Discourse within Social Justice and Land Claims

its high power of influence over State authorities linked to the case, drove the PDMM to give up participating in this space for dialogue. ${ }^{36}$

According to Jane F. Collier, Bill Maurer, and Liliana SuárezNavaz, the legal system seems to ignore those differences in power that exist outside of law. Nevertheless, law plays a role in producing such differences in two ways: i) the ideal of equal treatment before law makes it difficult for law to deal with differences in power and enforces inequalities in the legal process; and ii) law constitutes people's identities based on differences, and demands people to express differences and similarities in order to enjoy equality. Thus, the fact that law is constructed to deal with abstract individuals whose equality is assumed both makes invisible and legitimates real inequalities. ${ }^{37}$

Given these inequalities, local, regional, national, and international actors have supported the community of Las Pavas to reduce their asymmetric relationship with Labrador Consortium, and to strengthen the peasants' ability to interact with state institutions and the consortium. ${ }^{38}$

36 Independent Commission Land Conflict - Las Pavas, Report Independent Evaluation of the Land Conflict in Las Pavas, Bolivar, Colombia, 18 (Ricardo Vargas, June Marie Mow, Mario Pérez \& Ángela Rivas, Body Shop, Christian Aid, June 2010). Available at: http:// www.abcolombia.org.uk/downloads/361_LasPavasReview_Spanish.pdf, http://www. christianaid.org.uk/images/laspavasreport.pdf

37 Jane F. Collier, Bill Maurer \& Liliana Suárez-Navaz, Sanctioned Identities: Legal Constructions of Modern Personhood, 2 Identities: Global Studies in Culture and Power, 1-2, 1-27, 12 (1996). Available at: https://www.researchgate.net/publication/233067118_Sanctioned_Identities_Legal_Constructions_of_Modern_Personhood

38 Independent Commission Land Conflict - Las Pavas, Report Independent Evaluation of the Land Conflict in Las Pavas, Bolivar, Colombia, 19 (Ricardo Vargas, June Marie Mow, Mario Pérez \& Ángela Rivas, Body Shop, Christian Aid, June 2010). Available at: http:// www.abcolombia.org.uk/downloads/361_LasPavasReview_Spanish.pdf, http://www. christianaid.org.uk/images/laspavasreport.pdf 


\section{THE TWO FACES OF LAW AND HUMAN RIGHTS WITHIN SOCIAL JUSTICE AND LAND CLAIMS}

Law may be understood as an arena for the promotion of interests, ${ }^{39}$ a site of power, ${ }^{40}$ or a site of competition for the creation of meanings. ${ }^{41}$ Law shapes and reshapes the terrain of power by defining meanings and relationships in the context of state power and violence. ${ }^{42} \mathrm{Law}$ is simultaneously the maker of hegemony and a means of resistance, as contestability is a crucial part of the power of law. Therefore, law not only reinforces hegemony through the making of consciousness, but law also shapes and is shaped by oppositional practices. ${ }^{43}$ This conceptualization of the power of law as fluid, dynamic, and comprised of social interactions shows the relative autonomy of the law. ${ }^{44}$

Eduard Palmer Thompson argued that the rule of law is an "unqualified human good" as it imposes inhibitions upon power, and therefore it establishes the defense of citizens from

39 Robert L. Kidder, Toward an Integrated Theory of Imposed Law, in The Imposition of Law, 289-306, 291 (Sandra B. Burman \& Barbara E. Harrell-Bond, eds., Academic Press, New York, 1979).

40 Sally Engle Merry, Colonizing Hawai' $i$ : The Cultural Power of Law, 265 (Princeton University Press, Princeton, New Jersey, 2000).

41 Pierre Bourdieu, The Force of Law: Toward a Sociology of the Juridical Field, 38 Hastings Law Journal, 805-853, 817 (1986). Available at: http://derechoycambiosocial.pbworks. com/f/bourdieu $\% 5$ B1\%5D.pdf

42 Sally Engle Merry, Colonizing Hawai' i: The Cultural Power of Law, 17 (Princeton University Press, Princeton, New Jersey, 2000).

43 Mindie Lazarus-Black \& Susan Hirsch, Introduction/Performance and Paradox: Exploring Law's Role in Hegemony and Resistance, in Contested States: Law, Hegemony, and Resistance, 1-34 1, 2, 9, 11, 20, 21 (Mindie Lazarus-Black \& Susan F. Hirsch, eds., Routledge, New York, 1994).

44 Sally Engle Merry discusses this dynamic in the following terms: "In the process of historical transformation, law clearly embodies the desires and interests of groups in power. But the law also provides a powerful system of meaning-making based on ideas of rights and equality. It supports reformist humanism as well capitalist transformation. Law was not just a mode of power for the dominant, but also an institution standing against the unbridled power of the market. It constrained the impact of the market on individuals and communities, although only through the mediation of local judges and attorneys and the capacities of individual litigants. (...) Law creates structures of legitimation for relations of power that already exist, acting in a conservative fashion to support existing systems of power and control. At the same time, the language of law provides a critique of systems that fail to provide equal rights for all in a universalizing discourse as well as an arena in which to challenge subordination." Sally Engle Merry, Colonizing Hawai' $i$ : The Cultural Power of Law, 264 (Princeton University Press, Princeton, New Jersey, 2000). 
arbitrary power. ${ }^{45}$ In consequence, the rule of law is instrumental to humanize both the exercise of power by the bourgeoisie and the class struggle. According to this logic, law may actually protect the interests of the subordinate class for two reasons. First, the role of law as a hegemonic legitimizing tool must incorporate elements of justice within the law, because "the essential precondition for the effectiveness of law, in its function as ideology, is that it shall display an independence from gross manipulation and shall seem to be just. It cannot seem to be so without upholding its own logic and criteria of equity; indeed, on occasion, by actually being just." ${ }^{, 46}$ Second, the ruled class is a stakeholder in upholding respect for law. "The ruled -if they could find a purse and a lawyer - would actually fight for their rights by means of law... When it ceased to be possible to continue the fight at law, men still felt a sense of legal wrong: the propertied had obtained their power by illegitimate means." ${ }^{97}$

Moreover, law has a liberating potential within struggles for transformation of power because symbols of law are multivocal. The multiplicity of meanings implies "the fact that never only but always many worlds are created" within the practice of creating legal meanings as framed by culture. ${ }^{48}$ Therefore, meanings of legal ideas and institutions shift in accordance with forces, actors, events, political agendas, and historical influences within local, national, and global contexts. As a result, people may manipulate legal rhetoric in courts and in other sites of oppositional practice to resist domination. These practices of resistance may remake relations of power through transforma-

45 Eduard Palmer Thompson, The Rule of Law, in Whigs and Hunters: The Origin of the Black Act, 439 (Pantheon Books, New York, 1975).

46 Eduard Palmer Thompson, The Rule of Law, in Whigs and Hunters: The Origin of the Black Act, 436 (Pantheon Books, New York, 1975).

47 Eduard Palmer Thompson, The Rule of Law, in Whigs and Hunters: The Origin of the Black Act, 434 (Pantheon Books, New York, 1975).

48 Robert M. Cover, The Supreme Court, 1982 Term - Foreword: Nomos and Narrative, 97 Harvard Law Review, 4, 4-68, 16 (1983). Available at: http://digitalcommons.law.yale.edu/ cgi $/$ viewcontent.cgi?article $=3690 \&$ context $=$ fss_papers 
tion of the systems of meaning and beliefs originally imposed by the dominant class. ${ }^{49}$

Specifically the political and moral conception of social justice within the human rights discourse, founded on dignity and equality, is considered as justification of the resistance against regimes of domination and subordination. ${ }^{50}$ This agenda emphasizes individual identity, recognition of difference, and the prohibition of discrimination. ${ }^{51}$ For these reasons, the discourse of rights within the law offers an important resource for political movements, since law both provides a language for resistance and promises power to protect rights. As a result, subordinate groups have mobilized rights to contest power using the discourse of law, not only within the legal arena, but also for political resistance as a source of standards. ${ }^{52}$

On the other hand, resistance within the law has limitations. According to Thomas Biolsi, law establishes hegemony and a language of control, which constitutes and regulates political struggles and empowerment. ${ }^{53}$ Law is a system of meanings that constructs identities, defines relationships, and determines boundaries in an authoritative arena. For instance, laws and legal actors construct social identities of virtuous and respectable individuals (non-criminal) as opposed to dangerous people (criminal), based on the authority of the state. This distinction

49 Mindie Lazarus-Black \& Susan Hirsch, Introduction/Performance and Paradox: Exploring Law's Role in Hegemony and Resistance, in Contested States: Law, Hegemony, and Resistance, 1-34, 1, 2, 9, 11 (Mindie Lazarus-Black \& Susan F. Hirsch, eds., Routledge, New York, 1994).

50 Jack Donnelly, Universal Human Rights in Theory and Practice, 44, 53 ( $2^{\text {nd }}$ ed., Cornell Paperbacks, Cornell University Press, Ithaca, 2003). Ronald Dworkin, Taking Rights Seriously, 272 (Harvard University Press, Cambridge, 1978).

51 Duncan Kennedy, Three Globalizations of Law and Legal Thought: 1850-2000, in The New Law and Economic Development. A Critical Appraisal, 19-73, 65-66 (Álvaro Santos \& David Trubek, eds., Cambridge University Press, Cambridge, New York, 2006).

52 Sally Engle Merry, Colonizing Hawai'i: The Cultural Power of Law, 13 (Princeton University Press, Princeton, New Jersey, 2000). Sally Engle Merry, Legal Pluralism and Legal Culture: Mapping the Terrain, in Legal Pluralism and Development: Scholars and Practitioners in Dialogue, 66-82 (Brian Z. Tamanaha, Caroline Mary Sage \& Michael J. V. Woolcock, eds., Cambridge University Press, Cambridge, 2012).

53 Thomas Biolsi, Bringing the Law Back In: Legal Rights and the Regulation of Indian-White Relations on Rosebud Reservation, 36 Current Anthropology, 4, 543-571, 558 (1995). Available at: http://www.academicroom.com/article/bringing-law-back-legal-rights-andregulation-indian-white-relations-rosebud-reservation 
between the criminal and non-criminal involves a powerful system of discipline and control. ${ }^{54}$ Law also constructs subjects by fixing identities, such as right-holder and victim. The definitions of right-holder and victim determine who is entitled to claim rights and which rights can be claimed. ${ }^{55}$ Furthermore, human rights and criminal law define some categories or labels to represent experiences in legal terms (e.g. gross human rights violations). The process of defining categories is a process of both inclusion and exclusion of some individuals, groups, and situations. ${ }^{56}$ Thus, it may generate empowerment and disempowerment.

In addition, the law has the power to orchestrate, mediate, and contain political struggles. ${ }^{57}$ Resistance within the law incorporates strategies to achieve inclusion in legal institutions according to the frameworks of the dominant institutions. This means that resistance occurs within the order created by the law. People presenting narratives within the judicial proceedings must try to describe themselves according to the boundaries established by the law, in order to be considered right-holders and victims. Consequently, the law determines the self-understanding, selfpresentation, and self-representation of individuals and communities in dialogue with the state. ${ }^{58}$

54 Sally Engle Merry, Colonizing Hawai'i: The Cultural Power of Law, 17, 262 (Princeton University Press, Princeton, New Jersey, 2000).

55 David William Kennedy, The International Human Rights Movement: Part of the Problem?, 15 Harvard Human Rights Journal, 101-126 (2002). Available at: http://www.law.harvard. edu/faculty/dkennedy/publications/humanrights.pdf

56 For instance, the international human rights traditionally focused on individuals, so they excluded the collective or group rights. However, "one dramatic illustration of the changing understanding of rights within the international legal system is the emergence of a conception of indigenous rights, attached to groups rather than individuals." Sally Engle Merry, Changing Rights, Changing Culture, in Culture and Rights: Anthropological Perspectives, 31-55, 40 (Jane K. Cowan, Marie-Bénédicte Dembour \& Richard A. Wilson, eds., Cambridge University Press, Cambridge, New York, 2001).

57 Thomas Biolsi, Bringing the Law Back In: Legal Rights and the Regulation of Indian-White Relations on Rosebud Reservation, 36 Current Anthropology, 4, 543-571, 558 (1995). Available at: http://www.academicroom.com/article/bringing-law-back-legal-rights-andregulation-indian-white-relations-rosebud-reservation

58 Sally Engle Merry, Changing Rights, Changing Culture, in Culture and Rights: Anthropological Perspectives, 31-55, 35-36 (Jane K. Cowan, Marie-Bénédicte Dembour \& Richard A. Wilson, eds., Cambridge University Press, Cambridge, New York, 2001). 
Thus, strategies of resistance within the law involve the incorporation of those opposed to the power structure, and the transformation of their self-representation and their approaches. These forms of resistance may inadvertently contribute to the disciplining and control of individuals and communities. Those who resist have to learn to speak the language of law and frame their complaints in terms of rights and entitlements. ${ }^{59}$ They have to know the technicalities of their rights and mechanisms for redress in order to engage effectively in the legal arena. Above all, the legal process may become the dominant strategy, consuming resources that may be devoted to political strategies. ${ }^{60}$

Given that the law may be simultaneously a tool of control and a means of resistance, Jane Comaroff and John L. Comaroff argue that law is a double-edged sword:

On one hand, it was a devastating weapon of warfare, like no other in its capacity to annihilate and dispossess without being seen to do anything at all. And yet the appeal to rights was a means that, over the long run, came to be used by black South Africans in self-protection. Not always successfully, but not always in vain either. More to the point, it often seemed to be the only real means to hand, since it was part of the technology of rule on which rested the inequalities and disablements from which they suffered. This is why the language of the law is reducible neither to a brute weapon of control nor simply to an instrument of resistance. ${ }^{61}$

Similarly, Mauricio García-Villegas argues that although production of law has been used as a strategy for legitimizing social domination, the law is a useful instrument for articulating emancipatory and oppositional practices. Social movements, individuals, and state representatives who take rights seriously - particularly judges - may mobilize the law and its symbols of protection of rights as a tool for resistance or emancipation

59 Sally Engle Merry, Colonizing Hawai' $i$ : The Cultural Power of Law, 219 (Princeton University Press, Princeton, New Jersey, 2000).

60 Sally Engle Merry, Colonizing Hawai' $i$ : The Cultural Power of Law, 220 (Princeton University Press, Princeton, New Jersey, 2000).

61 Jane Comaroff \& John L. Comaroff, Of Revelation and Revolution, 404 (University of Chicago Press, Chicago, 1997). 
against hegemonic power. ${ }^{62}$ García-Villegas claims that increasing appropriation of constitutional law and incorporation of the legal approach within strategies to claim social transformation by social movements reduces the risk of the law being a tool of domination. This counter-hegemonic use of law increases the chance that the law will become an instrument - among others- of social emancipation. ${ }^{63}$

To summarize, the literature on the relative autonomy of the law implies that the law is not only a tool of power, used to oppress the ruled, but also a tool for the ruled to use against their oppressors. Hence the ruled can also fight for their rights by means of law, including human rights law. Notably, law and the human rights discourse may be both a tool for emancipation and social transformation (protecting and empowering potential) as well as a set of constraints that limit rights claims (unprotecting and disempowering potential).

\section{A. The protecting and empowering potential of law and human rights in the Las Pavas case}

The human rights discourse offers a language or system of rhetoric on social justice to demand political change, ${ }^{64}$ which is legitimated by a global consensus. ${ }^{65}$ It provides a resource for parties in domestic litigation where treaties are binding in the legal system and the courts are independent. ${ }^{66}$ This is the case

62 Mauricio García-Villegas, El derecho como esperanza: constitucionalismo y cambio social en América Latina, con algunas ilustraciones a partir de Colombia, in ¿Justicia para todos? Sistema judicial, derechos sociales y democracia en Colombia, 201-233, 224 (Rodrigo Uprimny-Yepes, César Rodríguez-Garavito \& Mauricio García-Villegas, eds., Norma, Bogotá, 2006).

63 Mauricio García-Villegas, El derecho como esperanza: constitucionalismo y cambio social en América Latina, con algunas ilustraciones a partir de Colombia, in ¿Justicia para todos? Sistema judicial, derechos sociales y democracia en Colombia, 201-233, 226-227 (Rodrigo Uprimny-Yepes, César Rodríguez-Garavito \& Mauricio García-Villegas, eds., Norma, Bogotá, 2006).

64 Patricia Williams, The Alchemy of Race and Rights: Diary of a Law Professor, 158 (Harvard University Press, 1991).

65 Sally Engle Merry, Human Rights and Gender Violence: Translating International Law into Local Justice, 4 (University of Chicago Press, Chicago, 2006).

66 Beth A. Simmons, Mobilizing for Human Rights: International Law in Domestic Politics, 14 (Cambridge University Press, Cambridge, New York, 2009). 
in Colombia. The Constitutional Court incorporated human rights treaties at the constitutional level using the "constitutional block" doctrine (bloque de constitucionalidad). ${ }^{67}$ According to this doctrine, human rights treaties are one of the parameters for assessing the constitutionality of domestic laws. Additionally, the Constitutional Court frequently cites decisions by international courts and soft law instruments as authority since these jurisprudence and international law instruments interpret and develop treaties. All in all, "the system has become neomonistic, with new channels opening for the interpenetration of international and domestic law through judicial decision, legislation, and executive action." 68

The Constitutional Court incorporated the doctrine of victims' rights of the Inter-American Court (IACtHR) as part of the "constitutional block." "69 The IACtHR has developed a

67 Colombian Constitutional Court, Judgment C-225-95, May 18, 1995, reporting justice Alejandro Martínez-Caballero. Available at: http://www.corteconstitucional.gov. co/relatoria/1995/c-225-95.htm. For an overview of the constitutional block, Diego López-Medina \& Astrid Liliana Sánchez-Mejía, La defensa de la libertad: análisis de las relaciones entre ley, derechos fundamentales y derechos humanos en el Sistema penal colombiano (Fiscalía General de la Nación, Bogotá, 2008). Rodrigo Uprimny-Yepes, Bloque de constitucionalidad, derechos humanos y nuevo procedimiento penal, in Reflexiones sobre el nuevo sistema procesal penal, 25-71 (Consejo Superior de la Judicatura, Escuela Judicial Rodrigo Lara Bonilla, Bogotá, 2004. Available at: http://www.dejusticia.org/ files/r2_actividades_recursos/fi_name_recurso.47.pdf

68 Harold Hongju Koh, Why Do Nations Obey International Law? 106 The Yale Law Journal, 8, 2599-2659, 2631 (June 1997). Available at: http://digitalcommons.law.yale.edu/ fss_papers/2101/, http://digitalcommons.law.yale.edu/cgi/viewcontent.cgi?article=2897 \& context=fss_papers

69 Colombian Constitutional Court, Judgment C-228-02, April 3, 2002, reporting justices Manuel José Cepeda-Espinosa, Eduardo Montealegre-Lynett. Available at: http://www. corteconstitucional.gov.co/relatoria/2002/c-228-02.htm. Colombian Constitutional Court, Judgment C-370-06, May 18, 2006, reporting justices Manuel José Cepeda-Espinosa, Jaime Córdoba-Triviño, Rodrigo Escobar-Gil, Marco Gerardo Monroy-Cabra, Álvaro Tafur-Galvis, Clara Inés Vargas-Hernández. Available at: http://www.corte constitucional.gov.co/relatoria/2006/c-370-06.htm. Colombian Constitutional Court, Judgment C-454-06, June 7, 2006, reporting justice Jaime Córdoba-Triviño. Available at: http://www.corteconstitucional.gov.co/relatoria/2006/c-454-06.htm. Colombian Constitutional Court, Judgment C-209-07, March 21, 2007, reporting justice Manuel José Cepeda-Espinosa. Available at: http://www.corteconstitucional.gov.co/relatoria/2007/c-209-07. $\mathrm{htm}$. According to international human rights, the Constitutional Court: "rules as victims' rights (i) the State's obligation to investigate, prosecute and punish crimes, particularly those that involving serious violations of human rights, respect which there is international agreement banning their impunity, (ii) linking the rights of victims with respect for human dignity, (iii) the right of victims to have a prompt and effective judicial remedy for the satisfaction of their constitutional rights to truth, justice, reparation, and guarantee of non-repetition, (iv) the right of victims to reparation contains measures of restitution, 
significant body of jurisprudence regarding victims' rights to truth, justice, and comprehensive reparation..$^{70}$ According to the IACtHR, victims of gross or massive human rights violations have the right to a fair trial, judicial protection, and reparation. In addition, the IACtHR argues that the American Convention grants to victims, their families, and society a right to know the truth about violations of human rights. ${ }^{71}$

compensation, and rehabilitation, (v) the right of victims to the non-repetition of crimes (...)." Constitutional Court, Summary in English of judgment C-370/06. Available at: http://english.corteconstitucional.gov.co/sentences/C-370-2006.pdf

70 Inter-American Court of Human Rights, IACtHR, Case Velásquez-Rodríguez v. Honduras, Serie C 4, Judgment of July 29, 1988, Merits. Available at: http://www.corteidh. or.cr/docs/casos/articulos/seriec_04_ing.pdf. Inter-American Court of Human Rights, IACtHR, Case Aloeboetoe et al. v. Suriname, Serie C 15, Judgment of September 10, 1993, Reparations and Costs. Available at: http://www.corteidh.or.cr/docs/casos/articulos/ seriec_15_ing.pdf. Inter-American Court of Human Rights, IACtHR, Case of Garrido and Baigorria v. Argentina, Serie C 39, Judgment of August 27, 1998, Reparations and Costs. Available at: http://www.corteidh.or.cr/docs/casos/articulos/seriec_39_ing.pdf. Inter-American Court of Human Rights, IACtHR, Case Barrios Altos v. Peru (Chumbipuma Aguirre and others), Serie C 75, Judgment of March 14, 2001, Merits. Available at: http://www.corteidh.or.cr/docs/casos/articulos/seriec_75_ing.pdf. Inter-American Court of Human Rights, IACtHR, Case "Street Children" v. Guatemala (Villagrán-Morales et al.), Serie C 77, Judgment of May 26, 2001, Reparations and Costs. Available at: http:// www.corteidh.or.cr/docs/casos/articulos/seriec_77_ing.pdf. Inter-American Court of Human Rights, IACtHR, Case Maritza Urrutia v. Guatemala, Serie C 103, Judgment of November 27, 2003, Merits, Reparations and Costs. Available at: http://www. corteidh.or.cr/docs/casos/articulos/seriec_103_ing.pdf. Inter-American Court of Human Rights, IACtHR, Case of the 19 Merchants v. Colombia, Serie C 109, Judgment of July 5, 2004, Merits, Reparations and Costs. Available at: http://www.corteidh.or.cr/docs/ casos/articulos/seriec_109_ing.pdf. Inter-American Court of Human Rights, IACtHR, Case of the Mapiripán Massacre v. Colombia, Serie C 134, Judgment of September 15, 2005. Available at: http://www.corteidh.or.cr/docs/casos/articulos/seriec_134_ing.pdf. Inter-American Court of Human Rights, IACtHR, Case of the Pueblo Bello Massacre v. Colombia, Serie C 140, Judgment of January 31, 2006, Merits, Reparations and Costs. Available at: http://www.corteidh.or.cr/docs/casos/articulos/seriec_140_ing.pdf. Inter-American Court of Human Rights, IACtHR, Case Almonacid Arellano v. Chile, Serie C 154, Judgment of September 26 of 2006, Preliminary Objections, Merits, Reparations and Costs. Available at: http://www.corteidh.or.cr/docs/casos/articulos/seriec_154_ing. pdf. Inter-American Court of Human Rights, IACtHR, Case Escué Zapata v. Colombia, Serie C 165, Judgment of July 4 of 2007. Available at: http://www.corteidh.or.cr/docs/ casos/articulos/seriec_165_ing.pdf. Inter-American Court of Human Rights, IACtHR, Case Gomes Lund v. Brazil (Guerrilha do Araguaia), Serie C 219, Judgment of November 24 of 2010, Preliminary Objections, Merits, Reparations, and Costs. Available at: http:// www.corteidh.or.cr/docs/casos/articulos/seriec_219_ing.pdf. Inter-American Court of Human Rights, IACtHR, Case Gelman v. Uruguay, Serie C 221, Judgment of February 24 of 2011, Merits and Reparations. Available at: http://www.corteidh.or.cr/docs/casos/ articulos/seriec_221_ing.pdf

71 Organization of American States, OAS, American Convention on Human Rights, ACHR, Pact of San Jose, Costa Rica, 22 November 1969, articles 1, 8, 13, 25. Available at: http:// www.oas.org/dil/treaties_B-32_American_Convention_on_Human_Rights.htm 
The discourse of human rights and victims' rights to truth, justice, and reparation has been appropriated by national and local actors within struggles on social justice in order to name, blame, and claim ${ }^{72}$ their grievances as human rights violations. Thus, ordinary citizens and many local activists increasingly frame their moral, political, social, and economic claims in the language of human rights. ${ }^{73}$

The use of the language of human rights may contribute to truth production regarding gross human rights violations in the following manner. Rights are "the magic wand of visibility and invisibility, of inclusion and exclusion, of power and no power."74 In fact, this language gives voice to people who historically have been denied their voices. ${ }^{75}$ In addition, this framework has the symbolic power of naming injustices and creating the realities, subjects, and social groups named. ${ }^{76}$ Therefore, it generates a new cultural framework, establishing that some behaviors, traditionally accepted as normal, should be considered to be violations of human rights, a change that gives people the consciousness to fight against them. ${ }^{77}$

These potential benefits of the use of the language of human rights are clearly demonstrated in the Las Pavas case. Legal claims to protect the right to land of the community of Las

72 The framework of naming, blaming, claiming is developed in William L. F. Felstiner, Richard L. Abel \& Austin Sarat, The Emergence and Transformation of Disputes: Naming, Blaming, Claiming..., 15 Law \& Society Review, 3/4, 631-654 (1980). Available at: http://www-personal.umich.edu/ 1root/ConflictMgtConceptMap/Felstiner-Abel-SaratEmergence-of-Disputes-1981.pdf

73 Jack Donnelly, Universal Human Rights in Theory and Practice ( $2^{\text {nd }}$ ed., Cornell Paperbacks, Cornell University Press, Ithaca, 2003). Beth A. Simmons, Mobilizing for Human Rights: International Law in Domestic Politics, 15 (Cambridge University Press, Cambridge, New York, 2009). Richard A. Wilson, Conclusion: Tyrannosaurus Lex: the Anthropology of Human Rights and Transnational Law, in The Practice of Human Rights: Tracking Law between the Global and the Local, 342-369 (Mark Goodale \& Sally Engle Merry, eds., Cambridge University Press, London, New York, 2007).

74 Patricia Williams, The Alchemy of Race and Rights: Diary of a Law Professor, 164 (Harvard University Press, 1991).

75 Patricia Williams, The Alchemy of Race and Rights: Diary of a Law Professor, 160 (Harvard University Press, 1991).

76 Pierre Bourdieu, The Force of Law: Toward a Sociology of the Juridical Field, 38 Hastings Law Journal, 805-853, 838 (1986). Available at: http://derechoycambiosocial.pbworks. com/f/bourdieu $\% 5$ B1\%5D.pdf

77 Sally Engle Merry, Human Rights and Gender Violence: Translating International Law into Local Justice, 2, 227 (University of Chicago Press, Chicago, 2006). 
Human Rights Discourse within Social Justice and Land Claims

Pavas began in 2006. The first procedure was the extinction of property, which was based on the lack of land utilization by the registered owner. During the initial stages of this procedure, lawyers and official representatives emphasized issues related to the traditional legal perspective of property and possession, without including arguments based on human rights. Some state representatives violated human rights through actions such as: ignoring the human rights law by making formalistic interpretations of legal texts, ${ }^{78}$ and infringing constitutional and legal provisions.

In 2009, lawyers, scholars, and NGO supporters of the Las Pavas case began to invoke human rights law and constitutional law. A local police authority (Inspector de policía) decided to evict the peasants from Las Pavas, infringing constitutional and legal rules. ${ }^{79}$ Colombian law establishes that only judges can carry out this eviction proceeding in cases where a procedure for extinction of property is still pending. In this circumstance, the community filed a constitutional lawsuit (acción de tutela) to demand the protection of their violated constitutional rights. The Constitutional Court stated that the eviction was unconstitutional and ordered the protection of the community's rights to a dignified life, due process, and work. The Court highlighted that peasants from Las Pavas were victims of forced displacement, and thus they were particularly vulnerable and deserved special constitutional protection. The Constitutional Court also declared null and void the decisions by the local police authority (Inspector de policía) to evict the community of Las Pavas. In addition, the Constitutional Court asked INCODER to continue and complete as soon as possible the proceeding for extinction of property and other administrative proceedings related to the Las Pavas case. ${ }^{80}$

78 Colombian Institute for Rural Development, INCODER, Resolución 346, February 23 of 2010.

79 Inspección Única de El Peñón. Resolución 002, January 28 of 2009.

80 Constitutional Court, Judgment T-267-11, April 8, 2011, reporting justice Mauricio González-Cuervo. Available at: http://www.corteconstitucional.gov.co/relatoria/2011/t-267-11. htm, http://english.corteconstitucional.gov.co/sentences/T-267-2011.pdf 
From then on, lawyers, scholars, and NGO supporters of the Las Pavas case have translated the needs and aspirations of the community into the language of human rights. The naming, blaming, and claiming of this grievance in terms of human rights turned the discussion of a formal legal issue of property into a matter of forced displacement. The renaming of the situation of the Las Pavas community as a violation of human rights has had two symbolic effects: i) it provides a new interpretation of this social situation, and ii) it empowers the members of the community to maintain the claim of their right to land.

In addition, the reframing of the legal and political claims has provided powerful tools and increased the national visibility of the case. Significantly, the use of the language of human rights law has shifted the claim's audience from the local to the national and transnational level. This generates the political space to create alliances between actors and social organizations on local, national, and transnational levels. ${ }^{81}$ In the Las Pavas case, a network of regional and national NGOs and social organizations $^{82}$ with transformative agendas has played an important role in developing and supporting the claims. Supporters have implemented formal and informal mechanisms such as public protests and demonstrations, divulgation of the case through the mass media, lobbying with national and regional official representatives, and the return of the community to the land in $2011 .^{83}$

Notably, the human rights discourse has brought about an international audience. The local intermediaries have forged alliances with international NGOs (e.g. FIAN International -formerly Food First Information and Action Network-, Christian Aid, Christian Peacemaker Teams, etc.) that have

81 Sally Engle Merry, Human Rights and Gender Violence: Translating International Law into Local Justice, 2, 227 (University of Chicago Press, Chicago, 2006). Jack Donnelly, Universal Human Rights in Theory and Practice, 162 ( $2^{\text {nd }}$ ed., Cornell Paperbacks, Cornell University Press, Ithaca, 2003).

82 Some of the regional and national NGOs and social organizations supporters of Las Pavas case are: Programa de Desarrollo y Paz del Magdalena Medio, PDPMM; Comisión de Interlocución del Sur de Bolívar, Centro y Sur del Cesar, CISBCSC; Federación Agrominera del Sur de Bolívar, FEDEAGROMISBOL; and Corporación Sembrar.

$83 \mathrm{https}: / /$ retornoalaspavas.wordpress.com/category/4-abril-2011-regreso-a-las-pavas/ 
generated the internationalization of the conflict through formal and informal mechanisms. ${ }^{84}$ In addition, international actors have participated in judicial proceedings, supporting victims through briefs amici and monitoring the proceedings. This participation of international allies has transformed the asymmetric situation between unprivileged victims and powerful counterparties within litigation. Moreover, international law can "verticalize" local conflicts, meaning it lifts "questions of conflict resolution out of a local or regional context and raises it to a higher level, usually that of the nation-state or international court or commission." $"{ }^{85}$

Finally, the use of an international human rights discourse in the Las Pavas case has changed the dialogue with the state, since human rights treaties are considered part of the Constitution - block of constitutionality - in the Colombian context. The human rights law expanded the legal mechanism of filing claims, because the community, as a constitutional and human

84 For example: i) lobbying at international human rights organizations (United Nations Special Rapporteur on the Right to Food, the United Nations Special Rapporteur on Human Rights Defenders, the Human Rights Defenders Unit of the Inter-American Human Rights System, and the Office of the High Commissioner for Human Rights in Geneva) http://www.fian.org/library/publication/colombia_123_families_returns_to_the_las_ pavas_land/; ii) FIAN has initiated urgent actions asking its international membership to write to Colombian authorities on the case http://www.fian.org/library/publication/ colombia_123_families_returns_to_the_las_pavas_land/;iii) Christian Aid promoted the cancellation of the contract between The Body Shop and the palm oil company formal owner of Las Pavas http://www.christianaid.org.uk/whatwedo/partnerfocus/body-shoppraise-for-cutting-ties-with-palm-olive-supplier.aspx, http://www.guardian.co.uk/globaldevelopment/poverty-matters/2010/oct/11/body-shop-supplier-dispute-ethics, http:// www.guardian.co.uk/business/2010/oct/03/body-shop-palm-oil-supplier, http://www. guardian.co.uk/world/2009/sep/13/body-shop-colombia-evictions; iv) Christian Peacemaker Teams have realized public action in Europe http://www.cpt.org/cptnet/2011/03/28/ colombia-analysis-despite-arrest-threats-people-las-pavas-continue-struggle-their-; v) meetings with different international embassies in Bogota to elevate the profile of the case internationally http://www.cpt.org/cptnet/2011/03/28/colombia-analysis-despite-arrestthreats-people-las-pavas-continue-struggle-their-; vi) some international NGOs have participated in domestic legal procedures in several ways like: sending Amicus Curiae brief to judges in charge of the case and monitoring the compliance of judicial decisions by the Colombian governmenthttp://retornoalaspavas.wordpress.com/2011/12/09/apoyoa-la-comunidad-de-las-pavas-asocab-fian-internacional/, vii) the case has been made visible through national and international media.

85 Richard A. Wilson, Conclusion: Tyrannosaurus Lex: the Anthropology of Human Rights and Transnational Law, in The Practice of Human Rights: Tracking Law between the Global and the Local, 342-369, 355 (Mark Goodale \& Sally Engle Merry, eds., Cambridge University Press, London, New York, 2007). 
rights-holder, is entitled to bring constitutional lawsuits. The use of constitutional mechanisms has changed the audience within the state because it started a dialogue with the Constitutional Court. The Colombian Constitutional Court has a tendency for progressive judgments, even though there have been conservative justices and conservative decisions. The Court usually protects the rights of individuals and disadvantaged groups, and implements the social justice values of the 1991 Constitution. ${ }^{86}$ The use of the language of human rights law has also brought about the attention of other state representatives and public institutions receptive to human rights. Notably, in November 2013, the Unit for Integral Assistance and Reparations for Victims (Unidad para la Atención y Reparación Integral a las Víctimas) formally recognized members of the community of Las Pavas as victims of forced displacement.

\section{B. The unprotecting and disempowering potential of law and human rights in the Las Pavas case}

The Inter-American Court (IACtHR) emphasizes that states must exercise due diligence to prevent, investigate, and punish all violations of rights protected by the American Convention of Human Rights (ACHR). ${ }^{87}$ Significantly, the duty to investigate is an obligation of means and not of results. ${ }^{88}$ According to

86 Rodrigo Uprimny-Yepes, The Constitutional Court and Control of Presidential Extraordinary Powers in Colombia, 10 Democratization, 4, 46-69, 63 (2003). Available at: https:// www.researchgate.net/publication/233179441_The_constitutional_court_and_control_of_presidential_extraordinary_powers_in_Colombia

87 Inter-American Court of Human Rights, IACtHR, Case Velásquez-Rodríguez v. Honduras, Serie C 4, Judgment of July 29, 1988, Merits, par. 166, 172. Available at: http://www. corteidh.or.cr/docs/casos/articulos/seriec_04_ing.pdf. Inter-American Court of Human Rights, IACtHR, Case of Garibaldi v. Brazil, Serie C 203, Judgment of September 23 of 2009, Preliminary objections, Merits, Reparations, and Costs, par. 141. Available at: http://www.corteidh.or.cr/docs/casos/articulos/seriec_203_ing.pdf. Inter-American Court of Human Rights, IACtHR, Case Anzualdo Castro v. Peru, Serie C 202, Judgment of September 22 of 2009, Preliminary Objection, Merits, Reparations and Costs, par. 179. Available at: http://www.corteidh.or.cr/docs/casos/articulos/seriec_202_ing.pdf

88 Inter-American Court of Human Rights, IACtHR, Case of Garibaldi v. Brazil, Serie C 203, Judgment of September 23 of 2009, Preliminary objections, Merits, Reparations, and Costs, par. 113. Available at: http://www.corteidh.or.cr/docs/casos/articulos/seriec_203_ing.pdf. Inter-American Court of Human Rights, IACtHR, Case Godinez-Cruz 
this obligation, in cases of grave human rights violations, state authorities must initiate ex-officio a serious, impartial, immediate, exhaustive, and effective investigation using all available legal means. ${ }^{89}$ The objective of the investigation should be to determine the truth and explore all possible lines of inquiry to identify the perpetrators. ${ }^{90}$ For this reason, the state can be held responsible for failing to practice, order, or evaluate relevant evidence. ${ }^{91}$

The IACtHR argues that states have a duty to prevent impunity. ${ }^{92}$ The court also highlights the duty of the state to establish the truth through judicial proceedings, particularly in criminal justice. ${ }^{93}$ The IACtHR, on the basis of what can be characterized

v. Honduras, Serie C 5, Judgment of January 20 of 1989, Merits, par. 188. Available at: http://www.corteidh.or.cr/docs/casos/articulos/seriec_05_ing.pdf. Inter-American Court of Human Rights, IACtHR, Case Velásquez-Rodríguez v. Honduras, Serie C 4, Judgment of July 29, 1988, Merits, par. 177. Available at: http://www.corteidh.or.cr/docs/casos/ articulos/seriec_04_ing.pdf

89 Inter-American Court of Human Rights, IACtHR, Case Anzualdo Castro v. Peru, Serie C 202, Judgment of September 22 of 2009, Preliminary Objection, Merits, Reparations and Costs, par. 123. Available at: http://www.corteidh.or.cr/docs/casos/articulos/ seriec_202_ing.pdf. Inter-American Court of Human Rights, IACtHR, Case of the Pueblo Bello Massacre v. Colombia, Serie C 140, Judgment of January 31, 2006, Merits, Reparations and Costs, par. 143. Available at: http://www.corteidh.or.cr/docs/casos/ articulos/seriec_140_ing.pdf. Inter-American Court of Human Rights, IACtHR, Case Godinez-Cruz v. Honduras, Serie C 5, Judgment of January 20 of 1989, Merits, par. 188. Available at: http://www.corteidh.or.cr/docs/casos/articulos/seriec_05_ing.pdf

90 Inter-American Court of Human Rights, IACtHR, Case Escué Zapata v. Colombia, Serie C 165, Judgment of July 4 of 2007, par. 106. Available at: http://www.corteidh.or.cr/docs/ casos/articulos/seriec_165_ing.pdf

91 Inter-American Court of Human Rights, IACtHR, Case "Street Children" v. Guatemala (Villagrán-Morales et al.), Serie C 63, Judgment of November 19, 1999, Merits, par. 230. Available at: http://www.corteidh.or.cr/docs/casos/articulos/seriec_63_ing.pdf

92 The Court defines impunity as "the absence of any investigation, pursuit, capture, prosecution, and conviction of those responsible for the violations of rights protected by the American Convention." Inter-American Court of Human Rights, IACtHR, Case of the Ituango Massacres, Serie C 147, Judgment of July 1, 2006, Preliminary Objections, Merits, Reparations and Costs, par. 299. Available at: http://www.corteidh.or.cr/docs/casos/ articulos/seriec_148_ing.pdf. Inter-American Court of Human Rights, IACtHR, Case of the Mapiripán Massacre v. Colombia, Serie C 134, Judgment of September 15, 2005, par. 237. Available at: http://www.corteidh.or.cr/docs/casos/articulos/seriec_134_ing.pdf

93 The Inter-American Court of Human Rights argues: " 148 . The Court has previously ruled that the right to know the truth is included in the right of victims or their next of kin to have the harmful acts and the corresponding responsibilities elucidated by competent State bodies, through the investigation and prosecution provided for in Articles 8 and 25 of the Convention. 149. Once more, the Court wishes to highlight the important role played by the different Chilean Commissions (supra paras. 82(26) to 82(30)) in trying to collectively build the truth of the events which occurred between 1973 and 1990. Likewise, the Court appreciates that the Report of the Comision Nacional de Verdady Reconciliación (National Truth and Reconciliation Commission) includes Mr. Almonacid-Arellano's 
as a punitive approach, determines the criminal investigation and prosecution as the best method to protect victims' rights to truth and justice. Thus, the IACtHR attributes to the criminal process a central role as a technology of knowledge production within truth construction. This has an unprotecting and disempowering potential because of the limitations of criminal justice. ${ }^{94}$ The Las Pavas case illustrates how, ironically, the central role attributed to criminal justice to protect victims' rights had the opposite effect of unprotecting the victims, as they were criminalized and re-victimized.

In 2009, members of international $\mathrm{NGOs}^{95}$ brought complaints against the local police authority (Inspector de policía) who ordered the eviction of peasants from Las Pavas. They also asked various state representatives to adopt measures aimed at protecting and assisting the community of Las Pavas. These complaints generated a criminal investigation for forced displacement against the local police authority (Inspector de policía). ${ }^{96}$

A prosecutor in Cartagena led the criminal investigation for forced displacement under the 2004 Criminal Procedure Code (CPC).${ }^{97}$ While the lawyer of the community of Las Pavas

name and a brief summary of the circumstances of his execution. 150. Notwithstanding the foregoing, the Court considers it relevant to remark that the \historical truth $\bigotimes$ included in the reports of the above mentioned Commissions is no substitute for the duty of the State to reach the truth through judicial proceedings. In this sense, Articles 1(1), 8, and 25 of the Convention protect truth as a whole, and hence, the Chilean State must carry out a judicial investigation of the facts related to Mr. Almonacid-Arellano's death, attribute responsibilities, and punish all those who turn out to be participants." Inter-American Court of Human Rights, IACtHR, Case Almonacid Arellano v. Chile, Serie C 154, Judgment of September 26 of 2006, Preliminary Objections, Merits, Reparations and Costs. Available at: http://www.corteidh.or.cr/docs/casos/articulos/seriec_154_ing.pdf

94 In this section of the text, I will describe some problems of criminal justice as a mechanism to deal with human rights violations. It is important to note that this section does not intend to present a comprehensive analysis of problems of access to justice.

95 Patrick Bonner, Megan James, Richard Slinner, and Montserrat López brought the complaints. Prosecutor 1 Delegate before the Criminal Judges of the Specialized Circuit. Attorney General's Office - National Unit against Forced Displacement. Resolution, November 11, 2011, NUC 130016001128200912518.

96 Prosecutor 1 Delegate before the Criminal Judges of the Specialized Circuit. Attorney General's Office - National Unit against Forced Displacement. Resolution, November 11, 2011, NUC 130016001128200912518.

97 Colombia, Ley 906 de 2004, por la cual se expide el Código de Procedimiento Penal, 45.658 Diario Oficial, 1 de septiembre de 2004. Available at: http://www.secretariasenado.gov. co/senado/basedoc/ley_0906_2004.html 
Human Rights Discourse within Social Justice and Land Claims

conferred with the prosecutor, the latter failed to provide any information about the case and did not give victims, or their legal counselor, access to the files of the investigation. ${ }^{98}$ Thus, members of the community of Las Pavas suffered restrictions on their right to information, even though the Constitutional Court emphasizes that victims should have access to information from their first contact with state officials. ${ }^{99}$ Furthermore, the prosecutor failed to gather evidence or pursue investigation hypotheses suggested by the victims' legal counselor during the preliminary inquiry. ${ }^{100}$

In November 2011, the prosecutor decided to close the case. She justified this decision by arguing that the narrative of the victims was false, based on the following reasons. ${ }^{101}$ First, the prosecutor used a formalistic legal method to interpret Article 159 of the Colombian Criminal Code. ${ }^{102}$ This rule describes forced displacement as follows: "anyone who, during an armed conflict, without military justification, deports, expels or carries out a forced transfer or displacement of the civilian population from its own territory." The prosecutor interpreted this article as requiring displacement from the place of residence. This interpretation thus excluded the situation of the community of Las Pavas from the legal boundaries of forced displacement. In the Las Pavas case, the community was displaced from the land in which they developed their agricultural activities, but these peasants continued to live in Buenos Aires. The prosecutor argued that they were not displaced from their place of residence, so they could not be viewed as victims of forced displacement. ${ }^{103}$

98 Conversations with the legal counselor (Banessa Estrada).

99 Colombian Constitutional Court, Judgment C-1154-05, November 5, 2005, reporting justice Manuel José Cepeda-Espinosa. Available at: http://www.corteconstitucional.gov. co/relatoria/2005/C-1154-05.htm

100 Conversations with the legal counselor (Banessa Estrada).

101 Prosecutor 1 Delegate before the Criminal Judges of the Specialized Circuit. Attorney General's Office - National Unit against Forced Displacement. Resolution, November 11, 2011, NUC 130016001128200912518.

102 Colombia, Ley 599 de 2000, por la cual se expide el Código Penal, 44.097 Diario Oficial, 24 de julio de 2000. Available at: http://www.secretariasenado.gov.co/senado/basedoc/ ley_0599_2000.html

103 Prosecutor 1 Delegate before the Criminal Judges of the Specialized Circuit. Attorney General's Office - National Unit against Forced Displacement. Resolution, November 
Second, the prosecutor claimed that there was no evidence regarding the forced displacements of the community of Las Pavas. The prosecutor focused on the eviction of the peasants of Las Pavas ordered by a local police authority (Inspector de Policía) in 2009, which was alleged by members of international NGOs in the complaints. Notably, the prosecutor failed to deeply investigate instances of violent displacement that occurred in 2003 and 2006, even though the victims' attorney attempted to suggest evidence of these facts.

Overall, the prosecutor Miriam Martínez-Palomino argued that the alleged violent displacements did not happen. She emphasized that members of the community of Las Pavas did not file any criminal complaint in 2003 or 2006. She also highlighted that the peasant Pedro Moreno-Redondo, on behalf of the community of Las Pavas, filed the first complaint for forced displacement in 2009 but later retracted it in 2011. However, the prosecutor disregarded the fact that Moreno-Redondo had pulled back after he began to work for the company that benefited from the peasant displacement. Significantly, the prosecutor Martínez-Palomino failed to evaluate the probative value or force of particular evidences in the context of the case as a whole. ${ }^{104}$ In fact, she privileged evidence or pieces of information that denied the forced displacement. She favored evidence provided by the companies that purchased the land after the displacement and had property title over the land. ${ }^{105}$

The prosecutor concluded that the self-representation of the peasants of Las Pavas as victims of forced displacement was false. Additionally, she pointed out that some of the community leaders were not actual peasants, as some of them do not

11, 2011, NUC 130016001128200912518.

1042004 Criminal Procedure Code, Article 380 establishes that proofs and evidences should be assessed as a whole (principio de unidad de prueba). Colombia, Ley 906 de 2004, por la cual se expide el Código de Procedimiento Penal, 45.658 Diario Oficial, 1 de septiembre de 2004. Available at: http://www.secretariasenado.gov.co/senado/basedoc/ley_0906_2004. html

105 Prosecutor 1 Delegate before the Criminal Judges of the Specialized Circuit. Attorney General's Office - National Unit against Forced Displacement. Resolution, November 11, 2011, NUC 130016001128200912518. 
Human Rights Discourse within Social Justice and Land Claims

fit the stereotypes and common representations of peasants. For instance, one leader was a teacher and another was a state representative in the municipality. Moreover, the prosecutor claimed that some of the community leaders were guerrillas or had links with guerrilla groups. Above all, she argued that this case was a fraud orchestrated by the community of Las Pavas and local, national, and international NGOs. In consequence, the prosecutor suggested that some of the community leaders and their supporters must be criminally investigated. ${ }^{106}$ According to the prosecutor Martínez-Palomino, members of the community of Las Pavas were criminals rather than victims.

The Las Pavas case shows that criminal justice is a very limited form of production of truth due to problems of evidence resulting from the armed conflict. These complications are aggravated in cases on forced displacement, since it is very difficult to prove victims' entitlements to the land. Some reasons for this are the multiplicity of victims that may have rights over the same land, "the obsolete nature of the country's information system on the juridical status of properties, the precariousness that has traditionally characterized rights over land, and the sophisticated legal transactions used by evictors to hide the illegality of their possessions."107

Furthermore, the Las Pavas case exemplifies the obstacles that victims face when participating in criminal proceedings under the 2004 Criminal Procedure Code. ${ }^{108}$ The lack of strong

106 Prosecutor 1 Delegate before the Criminal Judges of the Specialized Circuit. Attorney General's Office - National Unit against Forced Displacement. Resolution, November 11, 2011, NUC 130016001128200912518.

107 María Paula Saffon, The Project of Land Restitution in Colombia: An Illustration of the Civilizing Force of Hypocrisy?, 12 Revista Estudios Socio-Jurídicos, 2, 109-194, 147 (2010). Available at: http://revistas.urosario.edu.co/index.php/sociojuridicos/article/ viewFile/1368/1258

108 For instance, petitions of victims' attorneys to prosecutors to gather evidence or pursue investigation hypotheses during the preliminary inquiry and investigation stages are only suggestions under the 2004 Criminal Procedure Code (CPC). In fact, decisions by prosecutors are not subject to appeal. If prosecutors refuse to collect evidence, victims and their lawyers can gather evidence on their own. The drawback is that victims and NGOs usually do not have the financial resources to pay the costs of expert evidence. In contrast, the 2000 CPC established that victims' lawyers could submit formal requests in relation to evidence. According to the previous code, prosecutors had a duty to provide justifications when they rejected the requests for evidence. Subsequently, victims' attorneys 
and precise participatory rights and the inaccurate assumption that prosecutors represent the interests of victims particularly interferes with the rights of victims of human rights abuses. Prosecutorial representation of victims of human rights violations is insufficient to protect the rights and interests of victims because of the following reasons. First, some prosecutors lack the autonomy, impartiality, or willingness necessary to prosecute abuses perpetrated by other state representatives. ${ }^{109}$ Indeed, some scholars argue that the state may have a conflict of interest in such cases. Notably, in certain cases such as Las Pavas, prosecutors have labeled victims as members of guerrillas or terrorists, so prosecutors are reluctant to protect victims' rights and interests. Additionally, many human rights violations occurred within complex panoramas of multiple armed actors and sources of power. Some prosecutors do not want to process those cases because of their alliances with the perpetrators or out of fear. ${ }^{110}$

As a result, in many cases, there are conflicts between the case theories of prosecutors and the victims. In such cases, restrictions on direct victim participation may prevent the public record from including the victims' version of the truth, which may affect the right of victims to truth. Given that victims are marginalized

could appeal these decisions. The 2000 CPC also established that the state had to pay the expenses of collecting evidence asked by victims. In addition, in the 2000 CPC, victims had the status of full parties and had autonomy to participate in all criminal proceedings and present evidence. By contrast, the 2004 CPC and the Constitutional Court establish limited participation of victims and their attorneys at trial. Colombia, Ley 599 de 2000, por la cual se expide el Código Penal, 44.097 Diario Oficial, 24 de julio de 2000. Available at: http://www.secretariasenado.gov.co/senado/basedoc/ley_0599_2000.html. Colombia, Ley 600 de 2000, por la cual se expide el Código de Procedimiento Penal, 44.097 Diario Oficial, 24 de julio de 2000. Available at: http://www.secretariasenado.gov.co/senado/ basedoc/ley_0600_2000.html. Colombia, Ley 906 de 2004, por la cual se expide el Código de Procedimiento Penal, 45.658 Diario Oficial, 1 de septiembre de 2004. Available at: http://www.secretariasenado.gov.co/senado/basedoc/ley_0906_2004.html

109 For instance, human rights organizations have claimed that some state authorities have contributed to the production of impunity for cases of "false positives". Fundación para la Educación y el Desarrollo, FEDES, Soacha: La punta del iceberg. Falsos positivos e impunidad (Camilo Castellanos, dir., Fundación para la Educación y el Desarrollo, FEDES, Bogotá, 2010). Available at: https://colectivosurcacarica.files.wordpress. com/2010/06/informewebbaja.pdf

110 In 2004, various lawyers denounced that the prosecutor from Cartagena had links with paramilitaries. Los sonados casos de la fiscal que negó que los campesinos de Las Pavas fueran victimas, December 15, 2011. Available at: http://lasillavacia.com/historia/ los-sonados-casos-de-la-fiscal-que-no-les-creyo-los-campesinos-de-las-pavas-30278 
from the production of knowledge within the truth construction in the criminal justice, any protection that the IACtHR tries to provide to victims is not guaranteed in practice. Moreover, restrictions on victim participation make it difficult for victims and social organizations to fight high levels of impunity of human rights abuses within criminal proceedings.

The Las Pavas case illustrates that criminal justice decisions, as an authoritative technology of production of knowledge, may reject the self-representation of people and may unilaterally shape their history. In some cases, there is a tension between the self-representation of victims as victims of human rights violations (based on general provisions of human rights) and the criminal law categories that represent experiences in restrictive legal terms. As a result, criminal law categories and legal methods may generate a gap between the victims' own representations and the official truth produced within criminal proceedings. ${ }^{111}$

In the Las Pavas case, the prosecutor's decision to close the investigation demonstrated a rejection of the self-representation by the community of Las Pavas as victims of forced displacement. Thus, the prosecutor ascribed to victims and their supporters the identity of criminals based on the authority of the state. This criminalization involves a powerful system of discipline and control. ${ }^{112}$ Some actors of civil society and the media have used the representation of the victims and their supporters as criminals to

111 For instance, according to Elizabeth F. Drexler, transitional institutions attempt to rewrite narratives to contribute to the production of truth; they prioritize certain institutional truths as collective identities. In her fieldwork in East Timor and in Indonesia, based on anthropological methods, she explores the interplay between transitional institutions and representations, and she concludes that the transitional institutions have failed to include the representations of the victims.

"Despite their different agendas and the constraints facing them, the three institutions have all publically enacted a version of events that emphasizes violence between Timorese in a time of war. At the same time, the conditions of possibility for such violence and the process through which it was subtly and systematically developed over two decades remain invisible in official institutions and representations of historical and legal truth." Elizabeth F. Drexler, Adressing the Legacies of Mass Violence and Genocide in Indonesia and East Timor, in Genocide: Truth, Memory and Representation, 219-246 (Alexander Laban Hinton \& Kevin Lewis O’Neill, eds., The Cultures and Practice of Violence Series, Duke University Press, Durham, 2009).

112 Sally Engle Merry, Colonizing Hawai' $i$ : The Cultural Power of Law, 17, 262 (Princeton University Press, Princeton, New Jersey, 2000). 
stigmatize these victims and their struggles. ${ }^{113}$ Some actors have suggested that these "false victims" are giving false testimonies in order to get undeserved benefits and attack the company's right to property. ${ }^{114}$ This discourse against the victims affected the protection of their human rights by some state officials. For instance, invoking the prosecutor's decision in the Las Pavas case, some state representatives cancelled previous decisions that protected peasants' rights, such as the humanitarian aid provided by some state agencies.

The victims, their supporters, social organizations, and some journalists criticized the prosecutor's decision to close the investigation in the Las Pavas case. As a result, Attorney General, Viviane Morales [January 12, 2011-March 6, 2012], visited Las Pavas in December 2011. She opened a new criminal investigation for forced displacement, arguing that this case deserved a thorough and careful examination. ${ }^{115}$ However, this investigation is still pending, and so far the criminal justice has failed to punish the offenders and ensure victims' rights. The protection of the

113 La historia de la organización que denunció "el falso desplazamiento" de las Pavas, December 7, 2011. Available at: http://www.lasillavacia.com/historia/la-historia-de-la-organizacionque-denuncio-el-falso-desplazamiento-de-las-pavas-30129. Desplazamiento de las Pavas. "No existió desplazamiento en Las Pavas": fiscal general. La jefe del ente investigador señaló que un grupo de campesinos de la región mintieron sobre el desalojo, El Espectador, Judicial, 1 de diciembre de 2011. Available at: http://www.elespectador.com/noticias/ judicial/no-existio-desplazamiento-pavas-fiscal-general-articulo-314396. Fiscalía dice que no hubo desplazamiento en Las Pavas. Hace seis meses la Corte ordenó devolver la finca a desplazados. Este sería nuevo fraude al Estado, El Tiempo, Justicia, December 1, 2011. Available at: http://www.eltiempo.com/archivo/documento/CMS-10862771

114 Comisión Colombiana de Juristas, CCJ, Declaración oral en el Consejo de Derechos Humanos de Naciones Unidas, 19 período de sesiones (5 de marzo de 2012). Available at: http://www.coljuristas.org/documentos/declaraciones/2012mar05_cdh19_tema3.pdf. La lección de Las Pavas, Revista Semana, Nación, 3 de diciembre de 2011. Available at: http:// www.semana.com/nacion/articulo/la-leccion-las-pavas/250317-3

115 Fiscal Viviane Morales visitó Las Pavas, Noticias Uno, La Red Independiente, December 8, 2011. Available at: http://noticiasunolaredindependiente.com/2011/12/08/noticias/ fiscal-viviane-morales-visit-las-pavas/. Fiscal Viviane Morales anunció nueva investigación por el caso de Las Pavas. Aseguró que después de reunirse con la fiscal de Cartagena Miriam Martínez Palomino y con el padre Francisco de Roux, encontró necesario abrir una nueva investigación de lo que ocurrió en la hacienda Las Pavas antes del año 2006, Revista Semana, Nación, December 5, 2011. http://www.semana.com/nacion/articulo/ fiscal-viviane-morales-anuncio-nueva-investigacion-caso-las-pavas/250426-3. Fiscalía comenzará nueva investigación sobre Las Pavas. Vivian Morales dijo que con este nuevo proceso se busca determinar la veracidad de las denuncias sobre el desplazamiento forzado de 123 familias en 2003. Available at: http://www.verdadabierta.com/victimas-seccion/ desplazados/3739-fiscalia-abrio-investigacion-en-el-caso-las-pava 
Las Pavas community's rights in this new criminal investigation will depend on the willingness of the prosecutor to represent victims' interests and ensure their rights.

To summarize, the IACtHR gives criminal justice a central role in dealing with gross human rights violations in order to protect victims' rights and eradicate impunity. However, this approach may have unprotecting and disempowering potential in the Colombian context. The Las Pavas case illustrates how, ironically, the central role attributed to criminal justice to protect victims' rights had the opposite effect of unprotecting the victims, as they were criminalized and re-victimized. In order to ensure victims' rights, it is necessary to expand victim participation in all criminal proceedings and rethink legal methods. Legal narrative within criminal proceedings should include representations of the victims. Legal actors should use methods of other disciplines such as anthropological tools and social mapping to translate claims of victims into institutional language. Furthermore, criminal investigations of systematic human rights violations should integrate a historical perspective, allowing criminal proceedings to correct past injustices. 
CONCLUSION

The analysis of the impact of the legal mobilization in the Las Pavas case illustrates two faces of the human rights discourse. On one hand, the mobilization based on the human rights discourse has protecting and empowering potential: human rights contribute to empowering underprivileged and excluded people within legal and political mobilization. The naming, blaming, and claiming of grievances in terms of human rights make visible unjust situations, and moreover, this discourse has been a powerful tool in the plaintiff's legal claims in the Las Pavas case. Furthermore, claims in terms of human rights have shifted the audience from the local to the national and international levels through the creation of alliances with social organizations and NGOs from regional, national, and transnational levels. This demonstrates the relative autonomy of the law, enabling the law to offer a space of emancipation and protection of the most excluded and underprivileged sectors in society, so that the law provides a useful resource for social movements to claim social justice.

On the other hand, the legal mobilization of the human rights discourse has unprotecting and disempowering potential: law creates a system of meanings that constructs subjects, relationships and boundaries, and is also a powerful system of discipline and control. Therefore, law shapes and constrains political struggles. Moreover, the protection of rights is contingent because it depends on the results of the competition and interaction of diverse actors in the juridical field. In the Las Pavas case, the mobilization of legal and human rights language within the institution of criminal justice had the effect of criminalizing the community. In this context, a further issue is whether the criminal justice proceedings are an adequate device to deal with gross human rights violations like forced displacement in Colombia. This involves an examination of the role of criminal justice within legal, political, and social processes to deal with deep economic, social, and political struggles. 
Consequently, the human rights discourse seems not to be a magic wand for achieving the protection of rights and the contestation of subordination. However, in some contexts it strongly contributes to empowering the marginalized, making injustices visible, and offering an alternative reality based on equality and dignity. At the very least, it can become a symbol of those ideals, inspiring social mobilization for change. 


\section{BIBLIOGRAPHY}

\section{Books}

Comaroff, Jane \& Comaroff, John L., Of Revelation and Revolution, volume two, The Dialectics of Modernity on a South African Frontier (University of Chicago Press, Chicago, 1997).

Comaroff, John L. \& Roberts, Simon, Rules and Processes: The Cultural Logic of Dispute in an African Context (University of Chicago Press, Chicago, 1981).

Cowan, Jane K.; Dembour, Marie-Bénédicte \& Wilson, Richard A., eds., Culture and Rights: Anthropological Perspectives (Cambridge University Press, Cambridge, New York, 2001).

Donnelly, Jack, Universal Human Rights in Theory and Practice $\left(2^{\text {nd }}\right.$ ed., Cornell Paperbacks, Cornell University Press, Ithaca, 2003).

Dworkin, Ronald, Taking Rights Seriously (Harvard University Press, Cambridge, 1978).

Emanuelli, María Silvia; Jonsén, Jennie \& Monsalve Suárez, Sofía, Red Sugar, Green Deserts: Latin American Report on Monocultures and Violations of the Human Rights to Adequate Food and Housing, to Water, to Land and to Territory (FIAN International/FIAN Sweden, formerly FoodFirst Information and Action Network, Halmstad, Sweden, 2009). Available at: http://www. fian.org/en/news/article/red_sugar_green_deserts_report_on_monocultures _and_human_rights/

Jaramillo-Sierra, Isabel Cristina \& Alfonso-Sierra, Tatiana, Mujeres, cortes y medios: la reforma judicial del aborto (Universidad de los Andes, Siglo del Hombre Editores, Bogotá, 2008).

López-Medina, Diego \& Sánchez-Mejía, Astrid Liliana, La defensa de la libertad: análisis de las relaciones entre ley, derechos fundamentales y derechos humanos en el Sistema penal colombiano (Fiscalía General de la Nación, Bogotá, 2008).

Merry, Sally Engle, Colonizing Hawai'i: The Cultural Power of Law (Princeton University Press, Princeton, New Jersey, 2000).

Merry, Sally Engle, Human Rights and Gender Violence: Translating International Law into Local Justice (University of Chicago Press, Chicago, 2006).

Nader, Laura \& Todd, Harry F., eds., The Disputing Process: Law in Ten Societies (Columbia University Press, New York, 1978).

Simmons, Beth A., Mobilizing for Human Rights: International Law in Domestic Politics (Cambridge University Press, Cambridge, New York, 2009).

Thompson, Eduard Palmer, The Rule of Law, in Whigs and Hunters: The Origin of the Black Act (Pantheon Books, New York, 1975).

Williams, Patricia, The Alchemy of Race and Rights: Diary of a Law Professor (Harvard University Press, 1991). 
Drexler, Elizabeth F., Adressing the Legacies of Mass Violence and Genocide in Indonesia and East Timor, in Genocide: Truth, Memory and Representation, 219-246 (Alexander Laban Hinton \& Kevin Lewis O’Neill, eds., The Cultures and Practice of Violence Series, Duke University Press, Durham, 2009).

García-Villegas, Mauricio, El derecho como esperanza: constitucionalismo y cambio social en América Latina, con algunas ilustraciones a partir de Colombia, in ¿Justicia para todos? Sistema judicial, derechos sociales y democracia en Colombia, 201-233 (Rodrigo Uprimny-Yepes, César Rodríguez-Garavito \& Mauricio García-Villegas, eds., Norma, Bogotá, 2006).

García-Villegas, Mauricio \& Uprimny-Yepes, Rodrigo, Corte Constitucional y emancipación social, en Emancipación social y violencia en Colombia, 463-511 (Boaventura de Sousa-Santos \& Mauricio García-Villegas, Norma, Bogotá, 2004).

Jackson, Jean E., Rights to Indigenous Culture in Colombia, in The Practice of Human Rights: Tracking Law between the Global and the Local, 204-241 (Mark Goodale \& Sally Engle Merry, eds., Cambridge University Press, London, New York, 2007).

Kennedy, Duncan, Three Globalizations of Law and Legal Thought: 1850-2000, in The New Law and Economic Development. A Critical Appraisal, 19-73 (Álvaro Santos \& David Trubek, eds., Cambridge University Press, Cambridge, New York, 2006).

Kidder, Robert L., Toward an Integrated Theory of Imposed Law, in The Imposition of Law, 289-306 (Sandra B. Burman \& Barbara E. Harrell-Bond, eds., Academic Press, New York, 1979).

Lazarus-Black, Mindie \& Hirsch, Susan, Introduction/Performance and Paradox: Exploring Law's Role in Hegemony and Resistance, in Contested States: Law, Hegemony, and Resistance, 1-34 (Mindie Lazarus-Black \& Susan F. Hirsch, eds., Routledge, New York, 1994).

Merry, Sally Engle, Changing Rights, Changing Culture, in Culture and Rights: Anthropological Perspectives, 31-55 (Jane K. Cowan, Marie-Bénédicte Dembour \& Richard A. Wilson, eds., Cambridge University Press, Cambridge, New York, 2001).

Merry, Sally Engle, Introduction: Conditions of Vulnerability, in The Practice of Human Rights: Tracking Law between the Global and the Local, 195-203 (Mark Goodale \& Sally Engle Merry, eds., Cambridge University Press, London, New York, 2007).

Merry, Sally Engle, Legal Pluralism and Legal Culture: Mapping the Terrain, in Legal Pluralism and Development: Scholars and Practitioners in Dialogue, 6682 (Brian Z. Tamanaha, Caroline Mary Sage \& Michael J. V. Woolcock, eds., Cambridge University Press, Cambridge, 2012).

Uprimny-Yepes, Rodrigo, Bloque de constitucionalidad, derechos humanos y nuevo procedimiento penal, in Reflexiones sobre el nuevo sistema procesal penal, 25-71 
(Consejo Superior de la Judicatura, Escuela Judicial Rodrigo Lara Bonilla, Bogotá, 2004).

Wilson, Richard A., Conclusion: Tyrannosaurus Lex: the Anthropology of Human Rights and Transnational Law, in The Practice of Human Rights: Tracking Law between the Global and the Local, 342-369 (Mark Goodale \& Sally Engle Merry, eds., Cambridge University Press, London, New York, 2007).

\section{Journals}

Abel, Richard L., The Rise of Capitalism and the Transformation of Disputing: from Confrontation over Honor to Competition for Property, 27 University of California at Los Angeles, UCLA Law Review, 223-255 (1979).

Biolsi, Thomas, Bringing the Law Back In: Legal Rights and the Regulation of Indian-White Relations on Rosebud Reservation, 36 Current Anthropology, 4, 543571 (1995). Available at: http://www.academicroom.com/article/bringing-lawback-legal-rights-and-regulation-indian-white-relations-rosebud-reservation

Bourdieu, Pierre, The Force of Law: Toward a Sociology of the Juridical Field, 38 Hastings Law Journal, 814-853 (1986). Available at: http://derechoycambiosocial. pbworks.com/f/bourdieu\%5B1\%5D.pdf

Collier, Jane F.; Maurer, Bill \& Suárez-Navaz, Liliana, Sanctioned Identities: Legal Constructions of Modern Personhood, 2 Identities: Global Studies in Culture and Power, 1-2, 1-27 (1996). Available at: https://www.researchgate.net/publication/233067118_Sanctioned_Identities_Legal_Constructions_of_Modern _Personhood

Cover, Robert M., The Supreme Court, 1982 Term - Foreword: Nomos and Narrative, 97 Harvard Law Review, 4, 4-68 (1983).

Felstiner, William L. F.; Abel, Richard L. \& Sarat, Austin, The Emergence and Transformation of Disputes: Naming, Blaming, Claiming..., 15 Law \& Society Review, 3/4, 631-654 (1980).

Galanter, Marc, Why the "Haves" Come out Ahead: Speculations on the Limits of Legal Change, 9 Law and Society Review, 1, Litigation and Dispute Processing: Part One, 95-160 (1974).

Kennedy, David William, The International Human Rights Movement: Part of the Problem?, 15 Harvard Human Rights Journal, 101-126 (2002).

Koh, Harold Hongju, Why Do Nations Obey International Law? 106 The Yale Law Journal, 8, 2599-2659 (June 1997). Available at: http://digitalcommons.law.yale. edu/fss_papers/2101/, http://digitalcommons.law.yale.edu/cgi/viewcontent. cgi? article $=2897 \&$ context=fss_papers

Saffon, María Paula, The Project of Land Restitution in Colombia: An Illustration of the Civilizing Force of Hypocrisy?, 12 Revista Estudios Socio-Jurídicos, 2, 109-194 (2010). Available at: http://revistas.urosario.edu.co/index.php/sociojuridicos/article/viewFile/1368/1258

Trubek, David M., Studying Courts in Context, 15 Law \& Society Review, 3/4, 
Human Rights Discourse within Social Justice and Land Claims

485-502 (1980).

Uprimny-Yepes, Rodrigo, The Constitutional Court and Control of Presidential Extraordinary Powers in Colombia, 10 Democratization, 4, 46-69 (2003). Available at: https://www.researchgate.net/publication/233179441_The_constitutional _court_and_control_of_presidential_extraordinary_powers_in_Colombia

\section{International treaties}

Organization of American States, OAS, American Convention on Human Rights, ACHR, Pact of San Jose, Costa Rica, 22 November 1969. Available at: http:// www.oas.org/dil/treaties_B-32_American_Convention_on_Human_Rights. htm

\section{Inter-American Court of Human Rights, IACtHR, cases}

Inter-American Court of Human Rights, IACtHR, Case Almonacid Arellano v. Chile, Serie C 154, Judgment of September 26 of 2006, Preliminary Objections, Merits, Reparations and Costs. Available at: http://www.corteidh.or.cr/docs/ casos/articulos/seriec_154_ing.pdf

Inter-American Court of Human Rights, IACtHR, Case Aloeboetoe et al. v. Suriname, Serie C 15, Judgment of September 10, 1993, Reparations and Costs. Available at: http://www.corteidh.or.cr/docs/casos/articulos/seriec_15_ing.pdf

Inter-American Court of Human Rights, IACtHR, Case Anzualdo Castro v. Peru, Serie C 202, Judgment of September 22 of 2009, Preliminary Objection, Merits, Reparations and Costs. Available at: http://www.corteidh.or.cr/docs/casos/ articulos/seriec_202_ing.pdf

Inter-American Court of Human Rights, IACtHR, Case Barrios Altos v. Peru (Chumbipuma Aguirre and others), Serie C 75, Judgment of March 14, 2001, Merits. Available at: http://www.corteidh.or.cr/docs/casos/articulos/ seriec_75_ing.pdf

Inter-American Court of Human Rights, IACtHR, Case Escué Zapata v. Colombia, Serie C 165, Judgment of July 4 of 2007. Available at: http://www.corteidh. or.cr/docs/casos/articulos/seriec_165_ing.pdf

Inter-American Court of Human Rights, IACtHR, Case of Garibaldiv. Brazil, Serie C 203, Judgment of September 23 of 2009, Preliminary objections, Merits, Reparations, and Costs. Available at: http://www.corteidh.or.cr/docs/casos/ articulos/seriec_203_ing.pdf

Inter-American Court of Human Rights, IACtHR, Case Gelman v. Uruguay, Serie C 221, Judgment of February 24 of 2011, Merits and Reparations. Available at: http://www.corteidh.or.cr/docs/casos/articulos/seriec_221_ing.pdf

Inter-American Court of Human Rights, IACtHR, Case Godinez-Cruz v. Honduras, Serie C 5, Judgment of January 20 of 1989, Merits. Available at: http:// www.corteidh.or.cr/docs/casos/articulos/seriec_05_ing.pdf 
Inter-American Court of Human Rights, IACtHR, Case Gomes Lund v. Brazil

(Guerrilha do Araguaia), Serie C 219, Judgment of November 24 of 2010, Preliminary Objections, Merits, Reparations, and Costs. Available at: http:// www.corteidh.or.cr/docs/casos/articulos/seriec_219_ing.pdf

Inter-American Court of Human Rights, IACtHR, Case Maritza Urrutiav. Guatemala, Serie C 103, Judgment of November 27, 2003, Merits, Reparations and Costs. Available at: http://www.corteidh.or.cr/docs/casos/articulos/ seriec_103_ing.pdf

Inter-American Court of Human Rights, IACtHR, Case of Garrido and Baigorria v. Argentina, Serie C 39, Judgment of August 27, 1998, Reparations and Costs. Available at: http://www.corteidh.or.cr/docs/casos/articulos/seriec_39_ing.pdf

Inter-American Court of Human Rights, IACtHR, Case of the 19 Merchants v. Colombia, Serie C 109, Judgment of July 5, 2004, Merits, Reparations and Costs. Available at: http://www.corteidh.or.cr/docs/casos/articulos/seriec_109_ing.pdf

Inter-American Court of Human Rights, IACtHR, Case of the Ituango Massacres, Serie C 147, Judgment of July 1, 2006, Preliminary Objections, Merits, Reparations and Costs. Available at: http://www.corteidh.or.cr/docs/casos/ articulos/seriec_148_ing.pdf

Inter-American Court of Human Rights, IACtHR, Case of the Mapiripán Massacre v. Colombia, Serie C 134, Judgment of September 15, 2005. Available at: http:// www.corteidh.or.cr/docs/casos/articulos/seriec_134_ing.pdf

Inter-American Court of Human Rights, IACtHR, Case of the Pueblo Bello Massacre v. Colombia, Serie C 140, Judgment of January 31, 2006, Merits, Reparations and Costs. Available at: http://www.corteidh.or.cr/docs/casos/ articulos/seriec_140_ing.pdf

Inter-American Court of Human Rights, IACtHR, Case "Street Children" v. Guatemala (Villagrán-Morales et al.), Serie C 63, Judgment of November 19, 1999, Merits. Available at: http://www.corteidh.or.cr/docs/casos/articulos/ seriec_63_ing.pdf

Inter-American Court of Human Rights, IACtHR, Case "Street Children" v. Guatemala (Villagrán-Morales et al.), Serie C 77, Judgment of May 26, 2001, Reparations and Costs. Available at: http://www.corteidh.or.cr/docs/casos/ articulos/seriec_77_ing.pdf

Inter-American Court of Human Rights, IACtHR, Case Velásquez-Rodríguez v. Honduras, Serie C 4, Judgment of July 29, 1988, Merits. Available at: http:// www.corteidh.or.cr/docs/casos/articulos/seriec_04_ing.pdf

\section{Colombian normativity}

Colombia, Decreto 747 de 1992, por el cual se dictan medidas policivas con el fin de prevenir las invasiones en predios rurales que están ocasionando la alteración del orden público interno en algunos departamentos, 40.444 Diario Oficial, 7 de mayo de 1992. Available at: http://www.dmsjuridica.com/CODIGOS/ LEGISLACION/decretos/1992/D0747de1992.htm 
Human Rights Discourse within Social Justice and Land Claims

Colombia, Decreto-Ley 2303 de 1989, Código de Procedimiento Agrario, 39.013 Diario Oficial, 7 de octubre de 1989. Available at: http://www.cancilleria.gov. co/sites/default/files/Normograma/docs/decreto_2303_1989.htm

Colombia, Ley 599 de 2000, por la cual se expide el Código Penal, 44.097 Diario Oficial, 24 de julio de 2000. Available at: http://www.secretariasenado.gov.co/ senado/basedoc/ley_0599_2000.html

Colombia, Ley 600 de 2000, por la cual se expide el Código de Procedimiento Penal, 44.097 Diario Oficial, 24 de julio de 2000. Available at: http://www. secretariasenado.gov.co/senado/basedoc/ley_0600_2000.html

Colombia, Ley 906 de 2004, por la cual se expide el Código de Procedimiento Penal, 45.658 Diario Oficial, 1 de septiembre de 2004. Available at: http://www. secretariasenado.gov.co/senado/basedoc/ley_0906_2004.html

Colombia, Ley 1708 de 2014, por medio de la cual se expide el Código de Extinción de Dominio, 49.039 Diario Oficial, 20 de enero de 2014. Available at: http:// www.secretariasenado.gov.co/senado/basedoc/ley_1708_2014.html

Colombian Institute for Rural Development, INCODER, Resolución 346, February 23 of 2010.

\section{Colombian jurisprudence}

Colombian Constitutional Court, Judgment C-225-95, May 18, 1995, reporting justice Alejandro Martínez-Caballero. Available at: http://www.corte constitucional.gov.co/relatoria/1995/c-225-95.htm

Colombian Constitutional Court, Judgment C-228-02, April 3, 2002, reporting justices Manuel José Cepeda-Espinosa, Eduardo Montealegre-Lynett. Available at: http://www.corteconstitucional.gov.co/relatoria/2002/c-228-02.htm

Colombian Constitutional Court, Judgment C-1154-05, November 5, 2005, reporting justice Manuel José Cepeda-Espinosa. Available at: http://www. corteconstitucional.gov.co/relatoria/2005/C-1154-05.htm

Colombian Constitutional Court, Judgment C-370-06, May 18, 2006, reporting justices Manuel José Cepeda-Espinosa, Jaime Córdoba-Triviño, Rodrigo Escobar-Gil, Marco Gerardo Monroy-Cabra, Álvaro Tafur-Galvis, Clara Inés Vargas-Hernández. Available at: http://www.corteconstitucional.gov. co/relatoria/2006/c-370-06.htm, http://english.corteconstitucional.gov.co/ sentences/C-370-2006.pdf

Colombian Constitutional Court, Judgment C-454-06, June 7, 2006, reporting justice Jaime Córdoba-Triviño. Available at: http://www.corteconstitucional. gov.co/relatoria/2006/c-454-06.htm

Colombian Constitutional Court, Judgment C-209-07, March 21, 2007, reporting justice Manuel José Cepeda-Espinosa. Available at: http://www.corte constitucional.gov.co/relatoria/2007/c-209-07.htm

Constitutional Court, Judgment T-267-11, April 8, 2011, reporting justice Mauricio González-Cuervo. Available at: http://www.corteconstitucional.gov. 
co/relatoria/2011/t-267-11.htm, http://english.corteconstitucional.gov.co/ sentences/T-267-2011.pdf

\section{Statements, reports, documents, briefs}

Comisión Colombiana de Juristas, CCJ, Declaración oral en el Consejo de Derechos Humanos de Naciones Unidas, 19 período de sesiones (5 de marzo de 2012). Available at: http://www.coljuristas.org/documentos/declaraciones/2012mar05_ cdh19_tema3.pdf

Comisión de Seguimiento a la Política Pública sobre el Desplazamiento Forzado, Consultoría para los Derechos Humanos y el Desplazamiento, CODHES, Proceso Nacional de Verificación, El reto ante la tragedia humanitaria del desplazamiento forzado: reconocer y resarcir debidamente los daños y perjuicios (2009). Available at: http://www.codhes.org/ codhes/images/Encuestas/ Vol $\% 2010 \% 20$ reconocer $\% 20 \mathrm{y} \% 20$ resarcir $\% 20$ debidamente $\% 201$ os $\% 20$ daos $\% 20$ sept $\% 202011 . p d f$

Consultoría para los Derechos Humanos y el Desplazamiento, CODHES, El desplazamiento forzado y la imperiosa necesidad de la paz, Informe Desplazamiento 2013 (Consultoría para los Derechos Humanos y el Desplazamiento, CODHES, Bogotá, 2014). Available at: http://www.acnur.org/t3/uploads/ media/2881_COI_Colombia_Informe_CODHES_2013.pdf?view=1

Corporación Sembrar \& Federación Agrominera del Sur de Bolívar, FEDEAGROMISBOL, Caso Hacienda Las Pavas. Los intereses económicos y políticos del despojo del territorio (n.d.). Available at: http://retornoalaspavas.files.wordpress.com/2011/02/intereses-politicos-y-economicos-del-despojo-las-pavas.pdf

Fundación para la Educación y el Desarrollo, FEDES, Soacha: La punta del iceberg. Falsos positivos e impunidad (Camilo Castellanos, dir., Fundación para la Educación y el Desarrollo, FEDES, Bogotá, 2010). Available at: https:// colectivosurcacarica.files.wordpress.com/2010/06/informewebbaja.pdf

Independent Commission Land Conflict - Las Pavas, Report Independent Evaluation of the Land Conflict in Las Pavas, Bolivar, Colombia (Ricardo Vargas, June Marie Mow, Mario Pérez \& Ángela Rivas, Body Shop, Christian Aid, June 2010). Available at: http://www.abcolombia.org.uk/downloads/361_ LasPavasReview_Spanish.pdf, http://www.christianaid.org.uk/images/ laspavasreport.pdf

\section{Mass media}

Desplazamiento de las Pavas. "No existió desplazamiento en Las Pavas": Fiscal General. La jefe del ente investigador señaló que un grupo de campesinos de la región mintieron sobre el desalojo, El Espectador, Judicial, 1 de diciembre de 2011. Available at: http://www.elespectador.com/noticias/judicial/no-existiodesplazamiento-pavas-fiscal-general-articulo-314396

Fiscal Viviane Morales anunció nueva investigación por el caso de Las Pavas. Aseguró 
que después de reunirse con la fiscal de Cartagena Miriam Martínez Palomino y con el padre Francisco de Roux, encontró necesario abrir una nueva investigación de lo que ocurrió en la hacienda Las Pavas antes del año 2006, Revista Semana, Nación, December 5, 2011. http://www.semana.com/nacion/articulo/ fiscal-viviane-morales-anuncio-nueva-investigacion-caso-las-pavas/250426-3

Fiscal Viviane Morales visitó Las Pavas, Noticias Uno, La Red Independiente, December 8, 2011. Available at: http://noticiasunolaredindependiente. com/2011/12/08/noticias/fiscal-viviane-morales-visit-las-pavas/

Fiscalía dice que no hubo desplazamiento en Las Pavas. Hace seis meses la Corte ordenó devolver la finca a desplazados. Este sería nuevo fraude al Estado, El Tiempo, Justicia, December 1, 2011. Available at: http://www.eltiempo.com/ archivo/documento/CMS-10862771

La lección de Las Pavas, Revista Semana, Nación, 3 de diciembre de 2011. Available at: http://www.semana.com/nacion/articulo/la-leccion-las-pavas/250317-3

\section{Websites}

Body Shop Decision Praised as it Cuts Ties with Colombian Palm Oil Supplier, October 2010. Available at: http://www.christianaid.org.uk/whatwedo/partnerfocus/body-shop-praise-for-cutting-ties-with-palm-olive-supplier.aspx

Body Shop Deserves Respect for Putting Human Values above a Quick Buck, October 11, 2010. Available at: http://www.guardian.co.uk/global-development/ poverty-matters/2010/oct/11/body-shop-supplier-dispute-ethics

Body Shop Drops Supplier after Report of Peasant Evictions in Colombia, October 3, 2010. Available at: http://www.guardian.co.uk/business/2010/oct/03/bodyshop-palm-oil-supplier

Body Shop Ethics under Fire after Colombian Peasant Evictions, September 13, 2009. Available at: http://www.guardian.co.uk/world/2009/sep/13/body-shopcolombia-evictions

Colombia Analysis: Despite Arrest Threats, People of Las Pavas Continue to Struggle for Their Land. Available at: http://www.cpt.org/cptnet/2011/03/28/ colombia-analysis-despite-arrest-threats-people-las-pavas-continue-struggletheir-

Departamento Nacional de Planeación, DNP (2010). Estadísticas del sector agropecuario.

FIAN Internacional: Apoyo a la Comunidad de Las Pavas - ASOCAB, December 9, 2011. Available at: http://retornoalaspavas.wordpress.com/2011/12/09/apoyoa-la-comunidad-de-las-pavas-asocab-fian-internacional/

Fiscalía comenzará nueva investigación sobre Las Pavas. Vivian Morales dijo que con este nuevo proceso se busca determinar la veracidad de las denuncias sobre el desplazamiento forzado de 123 familias en 2003. Available at: http:// www.verdadabierta.com/victimas-seccion/desplazados/3739-fiscalia-abrioinvestigacion-en-el-caso-las-pava 
http://www.fian.org/library/publication/colombia_123_families_returns_to_the_ las_pavas_land/

https://retornoalaspavas.wordpress.com/category/4-abril-2011-regreso-a-laspavas/

La historia de la organización que denunció "el falso desplazamiento" de las Pavas, December 7, 2011. Available at: http://www.lasillavacia.com/historia/ la-historia-de-la-organizacion-que-denuncio-el-falso-desplazamiento-delas-pavas-30129

Los sonados casos de la fiscal que negó que los campesinos de Las Pavas fueran víctimas, December 15, 2011. Available at: http://lasillavacia.com/historia/ los-sonados-casos-de-la-fiscal-que-no-les-creyo-los-campesinos-de-laspavas-30278

MinAgricultura activó plan de choque para restituir y formalizar tierras a 130 mil familias. Available at: http://wsp.presidencia.gov.co/Prensa/2010/Octubre/ Paginas/20101015_06.aspx

Ministerio de Comercio, Industria y Turismo de Colombia, MinCIT (2010). Apuesta exportadora agropecuaria. Cultivos de tardio rendimiento.

Misael Payares: "Es la palabra de un campesino contra la de un empresario" (December 5, 2011). Available at: http://www.confidencialcolombia.com/noticia. html?noticia_id $=4354 \&$ status $=$ T

National Victims Unit, Victims Register: http://rni.unidadvictimas.gov. $\mathrm{co} / \mathrm{q}=$ node/107, http://www.unidadvictimas.gov.co/

United Nations High Commissioner for Refugees, UNCHR, 2015 UNHCR country operations profile - Colombia. Available at: http://www.unhor.org/cgi-bin/texis/ $\mathrm{vtx} /$ page? page $=49 \mathrm{e} 492 \mathrm{ad} 6 \&$ submit $=\mathrm{GO}$ 